\title{
INFORMING CONSUMERS ABOUT THEMSELVES
}

\author{
Oren Bar-Gill* and Franco Ferrari**
}

\begin{abstract}
Consumers make mistakes. Imperfect information and imperfect rationality lead to misperception of benefits and costs associated with a product. As a result, consumers might fail to maximise their preferences in product choice or product use. A proposed taxonomy of consumer mistakes draws attention to a less-studied category of mistakes: use-pattern mistakes - mistakes about how the consumer will use the product. Use-pattern mistakes are prevalent. Sellers respond strategically to use-pattern mistakes by redesigning their products, contracts and pricing schemes. These strategic design responses often exacerbate the welfare costs associated with consumer mistakes. From a policy perspective, focusing on disclosure regulation, the importance of usepattern mistakes requires more, and better, use-pattern disclosure. In particular, sellers should be required to provide individualised use-pattern information.
\end{abstract}

\section{Introduction}

Consumers make mistakes. Imperfect information and imperfect rationality lead to misperception of benefits and costs associated with a product. As a result, consumers might fail to maximise their preferences in product choice or product use. In this article, we offer a taxonomy of consumer mistakes, drawing attention to a less-studied category of mistakes: use-pattern mistakes. We argue that use-pattern mistakes are prevalent. Sellers respond strategically to use-pattern mistakes by redesigning their products, contracts and pricing schemes. These strategic design responses often exacerbate the welfare costs associated with consumer mistakes. From a policy perspective, focusing on disclosure regulation, we argue that the importance of use-pattern mistakes requires more, and better, use-pattern disclosure.

We begin, in Part 2, by distinguishing between two categories of information information about product attributes and information about product use. ${ }^{1}$ For example, the interest rate on a credit card and the penalty for late payment are attributes of the credit card product. Borrowing patterns and the incidence of late payment describe how the product is used. The total benefits and costs associated with a product are a function of both product attributes and use patterns. Total interest paid depends both on the interest rate and on the consumer's evolving balance. Total penalty charges depend both on the late fee and on the frequency of late payment. The important role of information has been recognised both in the economic analysis of consumer markets and in consumer protection law. To a large degree, however, both the law and the economics of consumer markets have focused on information about product attributes. This article emphasises the importance of product use information or lack thereof in explaining market behaviour and in effectively regulating consumer markets.

\footnotetext{
Professor of Law, New York University School of Law.

Professor of Law, New York University School of Law. We wish to thank Jenifer Arlen, Ian Ayres, Lucian Bebchuk, Omri Ben-Shahar, Richard Craswell, Clay Gillette, Ofer Grosskopf, Christine Jolls, Marcel Kahan, Ehud Kamar, Daryl Levinson, Ronald Mann, Florencia Marotta Wurgler, Avishalom Tor, Elizabeth Warren and workshop participants at Harvard, NYU, the University of Haifa and the University of Illinois for helpful comments. Special thanks to Anthony Ogus, Willem van Boom and the participants in the Rotterdam Workshop on Juxtaposing Autonomy and Paternalism in Private Law for valuable comments and discussions. We are also grateful to an anonymous referee for helpful comments and suggestions. Robin Moore, Tal Niv and Rebecca Stone provided excellent research assistance. Financial support from the Filomen D'Agostino and Max E. Greenberg Research Fund and from the Cegla Center for Interdisciplinary Research of the Law in Tel-Aviv University is gratefully acknowledged.

Product attributes affect product use. How a consumer uses a product depends on the product's functionality and on the product's price - both product attributes.
} 
The relevance of consumer mistakes - descriptively, normatively and prescriptivelydepends on the robustness and persistence of these mistakes in a market setting. A naïve view would dismiss mistakes based on imperfect use information as short-lived or even non-existent. Product use depends on consumer wants and needs, and consumers are supposed to know their own wants and needs. The ideal homo oeconomicus consumer has perfect information about his preferences. But his real-world counterpart does not. Moreover, product use depends on external influences as well as on internal preferences. Accordingly, even the ideal, perfectly rational consumer might suffer from imperfect use information.

After describing the two main subjects of consumer mistakes - product attributes and product use - we proceed, in Part 3, to consider regulatory responses to such market failure. In particular, we consider disclosure regulation. We focus on disclosure regulation for several reasons. First, disclosure is the most benign form of intervention, facilitating, rather than inhibiting, the operation of markets. ${ }^{2}$ Second, and related, disclosure mandates have proven to be the most politically feasible, often the only politically feasible, form of regulation in many contexts. ${ }^{3}$ Finally, this article studies the problem of consumer mistakes. Since mistakes can often be traced back to lack of information, disclosure of information is the natural starting point for solving the mistake problem. This does not mean that disclosure is a perfect fix in all mistake cases. Nor does it mean that disclosure is always superior to other forms of regulation or to no regulation at all. The costs and limits of information disclosure are well known. Our goal is not to idealise disclosure. Rather, recognising the prevalence of disclosure regulation, our goal is to help regulators design more effective disclosure mandates. We argue that disclosure requirements should match the type of information deficit that caused the market failure. When market failure is caused by mistakes about product attributes, the solution is disclosure of product attributes. And when market failure is caused by mistakes about product use, the solution is disclosure of use patterns.

A brief survey of existing disclosure requirements demonstrates the prevalence of disclosure mandates focused on product attributes. Use-pattern disclosure requirements are more limited and less effective. Consumers receive information on the proper use of products. For example, the Federal Trade Commission (FTC) in the United States, as well as parallel agencies in several European states, require clothes manufacturers to provide information on how to properly clean the clothes. ${ }^{4}$ Consumers also receive indirect use information when product attribute information is based - explicitly or implicitly - on some assumption about average or typical use. For example, a cigarette's tar and nicotine ratings, which are certified by the FTC, assume a certain intensity of smoking - a 2-second, 35-millilitre puff every minute. ${ }^{5}$ We argue for enhanced usepattern disclosure. In particular, we argue for direct disclosure of average use-pattern information. For example, credit card issuers can be required to disclose the average likelihood of paying late (and triggering a penalty fee) or, even better, the amount that an average consumer pays in late fees each year. More importantly, we argue that in certain markets sellers should be required to provide individual-use information. Elaborating on the previous example, credit card issuers can be required to tell each consumer how much he or she paid in late fees over the past year. This prescription is feasible and desirable in markets, such as the credit card market, where sellers maintain long-term relationships with their customers and thus voluntarily collect individual-use information.

The call for enhanced use-pattern disclosure, and specifically the emphasis on individual-use disclosure, challenges the conventional wisdom about information and

\footnotetext{
2 See C. Camerer et al., 'Regulation for Conservatives: Behavioral Economics and the Case for “Asymmetric Paternalism"” (2003) 151 U. Pa. L. Rev. 1211; C.R. Sunstein and R.H. Thaler, 'Libertarian Paternalism is not an Oxymoron' (2003) 70 U. Chi. L. Rev. 1159.

3 See e.g. O. Bar-Gill, 'Seduction by Plastic' (2004) 98 NW. U. L. Rev. 1373 at 1374, n. 3 (describing the failed attempts to enact usury ceilings for credit cards and the resort to disclosure regulation); R.J. Mann, Charging Ahead: The Growth and Regulation of Payment Card Markets (2006) at 159 (describing disclosure mandates as 'a common compromise solution in the American regulatory regime').

${ }_{4}$ See below Section 3.1. However, there is no such regulation at the European level. Id.

5 See below Section 3.2.
} 
disclosure in consumer markets. This conventional wisdom recognises that sellers often have superior product attribute information and that it may be desirable to require them to disclose this information to consumers. On the other hand, the conventional wisdom largely overlooks the welfare-enhancing potential of use-pattern disclosure, because it assumes that consumers, not sellers, have superior use-pattern information. We argue that this assumption, while clearly true in some markets, is false in others. In important consumer markets, sellers know more about the consumers' use patterns than the consumers themselves. In these markets, use-pattern disclosure may well be desirable. ${ }^{6}$

Finally, disclosure mandates can be more important when the subject of the mandate is use-pattern information. Sellers have strong incentives to voluntarily disclose product attribute information. By disclosing this seller-specific information, high-quality sellers can convince consumers to buy from them, rather than from a low-quality competitor. (And since only low-quality sellers remain silent, consumers will be able to easily identify the low-quality sellers.) Voluntary disclosure of use-pattern information is less likely. Since the information is consumer-specific, not seller-specific, if one seller discloses the use-pattern information, the nowinformed consumer may well purchase the product from a different seller. When voluntary disclosure is less reliable, the case for disclosure mandates becomes stronger.

We focus on mandatory disclosure as the prototypical autonomy-enhancing, minimally paternalistic regulatory technique. But our analysis also questions whether disclosure mandates are as benign as they are believed to be. First, the notion of informing consumers about themselves smacks of paternalism. Second, and more important, our analysis highlights the complex set of regulatory design choices that result in a mandatory disclosure rule. Since imperfectly rational consumers cannot process endless amounts of information, optimal disclosure rules must carefully pick what information is disclosed and what information remains undisclosed (or what information is emphasised and what information is de-emphasised). In effect, the regulator must decide what information is more important for consumers and what information is less important for consumers. Even with disclosure, some measure of paternalism cannot be avoided.

\section{The Object of Consumer Mistakes: Two Categories}

This article is about mistakes, specifically, consumer mistakes affecting product choice and product use. A mistake can be the result of imperfect information or imperfect rationality. Why do consumers have only imperfect information? Why and in what way do consumers deviate from the perfect rationality ideal? These are all important questions - important questions that are largely sidestepped in this article. Rather, our goal is to conceptualise and categorise mistakes, in Part 2, and to study regulatory responses to mistakes, in Part 3.

\subsection{Two Categories of Consumer Mistakes}

Informed choice assumes two distinct categories of information: information about product attributes and information about how the product will be used. One way to view the distinction between product-attributes information and product use information is by tracing the source of the information. Product attribute information, like the product itself, is created by the manufacturer. The manufacturer is the source of the information. Product use is a function of both the product's attributes and the consumer's wants and needs. Product-use information has two sources - the manufacturer and the consumer. A different categorisation would focus on these two sources and distinguish between manufacturer (or seller) information and consumer information. Consumer information,

\footnotetext{
While the conventional wisdom, and the regulatory landscape that is based on it, focus on product attribute disclosure, there are important examples of use-pattern disclosures, including direct average-use disclosures and individual-use disclosures, both in existing law and in law reform proposals. See below Part 3 . These examples, however, serve as the exception that proves the rule.
} 
i.e. information on consumer wants and needs, can be further divided into two categories or sources of information: an internal source, consisting of consumer preferences, and an external source, consisting of the sum of external forces that affect the benefit to the consumer from using the product.

Consumer protection law is concerned with imperfect information on the part of consumers. Traditional consumer protection analysis and policy focus on lack of information about product attributes. ${ }^{\top}$ This emphasis on product attribute information can be traced back to the rational choice foundations of traditional consumer protection analysis. Rational choice theory assumes that individuals have perfect information about their own preferences. To the extent that use is determined by consumer preferences, the rational choice model assumes perfect information about use patterns. Unfortunately, few consumers are perfectly rational. And imperfectly rational consumers might have imperfect information concerning their own preferences. ${ }^{8}$ Moreover, as explained above, how a consumer will use a product depends on external influences as well as on internal preferences. Even a perfectly rational consumer may have only imperfect information about these external influences.

Consider a lawnmower. The value of a lawnmower to a consumer depends on attributes of the lawnmower and on how frequently the consumer will want or need to mow his or her lawn. How often the lawnmower will be used depends, in turn, on attributes of the lawnmower, on consumer preferences and on external factors influencing the consumer's need to mow the lawn. The attributes of the lawnmower matter, for example, because, a better lawnmower is less burdensome to operate and thus will be used more often. Consumer preferences matter, because a consumer who cares more about his or her lawn will use the lawnmower more often. And external forces, like rainfall and soil condition, matter, because they affect the speed with which grass grows. To make a fully-informed decision whether to purchase a lawnmower and which lawnmower to purchase the consumer must have information on all of these factors. Yet consumer protection law, with its focus on product attribute information, pays insufficient attention to other factors affecting product use.

Or consider a credit card. Focusing on the financing component of the credit card product, the value of a credit card depends on product attributes, specifically the interest rate. The value of the product also depends on how it will be used - on how much the consumer will borrow. The extent of borrowing, in turn, depends on: (1) product attributes such as the interest rate; (2) the consumer's intertemporal consumption preferences; and (3) external forces affecting the consumer's desire to borrow or need to borrow, such as present and expected available income and conditions affecting the demand for funds, e.g. illness or divorce. Policy-makers have been concerned about mistakes in the credit card market. Their response, however, has largely been targeted at product attribute information. The Truth in Lending Act, for example, mandates conspicuous disclosure of credit card interest rates. Use-pattern mistakes that are not caused by imperfect information about interest rates have received less attention. ${ }^{9}$

\subsection{The Persistence of Use-Pattern Mistakes}

Many consumer mistakes are short-lived. Consumers quickly learn to avoid these mistakes and market forces work to eliminate them. Accordingly, consumer mistakes are important, descriptively and normatively, only if they can withstand these mistakecorrection forces. The persistence of any mistake, including use-pattern mistakes, is an

\footnotetext{
See below Part 3.

8 We are assuming that consumers have fixed preferences, but might be imperfectly aware of these preferences at the time when they decide whether to buy a certain product or which type of product to buy. Our departure from the neoclassical model is thus limited. A more substantial departure would recognise that some preferences are not fixed, but rather constructed, and that information, including information provided by sellers, affects the construction of preferences. Relaxing the fixed-preferences assumption raises important descriptive and normative questions; questions which we do not address in this article. 9 See below Part 3.
} 
empirical question. ${ }^{10}$ A market-specific inquiry is necessary to determine whether the specific market is afflicted by a mistake-driven market failure. But before we turn to empirics, we offer several observations on the theoretical possibility of persistent usepattern mistakes. We argue that learning, an important mistake-correction force, might be weaker in the use-pattern context. We then argue that another mistake-correction force, education efforts by sellers, might also be less effective in curing use-pattern mistakes.

\subsubsection{Learning by Consumers}

Use-pattern mistakes are based on misperception about product attributes as well as about the consumer's own wants and needs. Learning about internal factors influencing a consumer's wants and needs - about preferences - should be easy and quick. Learning about external factors, namely product attributes and external forces influencing the consumer's wants and needs, can be more or less effective depending on context. ${ }^{11}$ But there are general forces working against learning of use-pattern information. Learning can be both intrapersonal and interpersonal. In many markets, interpersonal learning is an important safeguard against persistent consumer mistakes. And interpersonal learning is less effective in curing use-pattern mistakes. ${ }^{12}$

Interpersonal learning is quick and effective when the object of learning is a standardised product. ${ }^{13}$ But not all products are standardised. And when the product is not standardised interpersonal learning becomes slower. With a standardised good, when a consumer discovers, through use, a certain hidden feature of the product, he or she can share this information with family and friends. Since the information pertains to a standardised good it is relevant to others. But if the good is not a standardised good such interpersonal learning will be less effective. With a non-standardised good the information obtained by one consumer might not be relevant to another consumer who purchased a different version of the non-standard good. ${ }^{14}$

When the nature of the product is more broadly defined to include the potential uses of the product, then the group of standardised products shrinks. In particular, even an otherwise standardised product is non-standardised with respect to use patterns, when different consumers use the product in different ways. And this can inhibit learning of use-pattern information. After using a product for some time, a consumer will obtain valuable use-pattern information. But this information, while valuable to this specific consumer, may be of little value to another consumer who will use the same product differently. ${ }^{15}$

\footnotetext{
10 See A. Tversky and D. Kahneman, 'Rational Choice and the Framing of Decisions' in R.M. Hogarth and M.W. Reder (eds.), Rational Choice: The Contrast Between Economics and Psychology (1987) at 91 ('The claim that the market can be trusted to correct the effect of individual irrationalities cannot be made without supporting evidence.').

11 Learning from one's mistakes relies on timely, clear and painful feedback that the decision was in fact a mistake. See C. Camerer, "Comments on "Some Implications of Cognitive Psychology for Risk Regulation", by R. Noll and J. Krier' (1990) 19 J. Legal Stud. 791 at 794 (learning occurs when the outcome is prompt and unambiguous); R. Korobkin, 'Bounded Rationality, Standard Form Contracts, and Unconscionability' (2003) 70 U. Chi. L. Rev. 1203 (citing references). An impediment to learning is that people attribute good outcomes to skill and bad outcomes to (bad) luck. See J. Arlen, 'Comment: The Future of Behavioral Economic Analysis of Law' (1998) 52 Vand. L. Rev. 1765 at 1783 (citing M. Bazerman, Judgment in Managerial Decision Making (1998)). On the limits of learning, see generally Tversky and Kahneman, above note 10, at 90-91; H. Latin, “'Good” Warnings, Bad Products, and Cognitive Limitations' (1994) 41 UCLA L. Rev. 1193 at 1252-1255. Generally, infrequent mistakes or mistakes that generate infrequent feedback are less susceptible to correction by learning.

12 Learning - both intrapersonal learning and interpersonal learning - can occur within markets and across markets. Some use-pattern mistakes transcend market boundaries and are more amenable to cross-market learning than product attribute mistakes.

13 See e.g. R.A. Epstein, 'Behavioral Economics: Human Error and Market Corrections' (2006) 73 U. Chi. L. Rev. 111 at 120 (arguing that mistakes with respect to the value of a standardised product are unlikely to persist in the marketplace).

${ }_{14}$ See O. Bar-Gill, 'The Behavioral Economics of Consumer Contracts' (2008) 92 Minn. L. Rev. 749.

15 This is not to say that meaningful information cannot be conveyed. For example, one consumer can
} 
An important factor that facilitates learning is seller reputation. Seller reputation is commonly based on the quality of the seller's product, not on how consumers use the product. Accordingly, reputation, as facilitator of consumer learning, plays a smaller role in the learning of use-pattern information. Another form of learning is based on expert advice. Consumers, recognising their imperfect rationality and the imperfect information at their disposal, take steps to limit the mistakes that they make. In particular, consumers seek advice and consult experts before entering the market. ${ }^{16}$ This indirect form of learning is also less effective when product use information is concerned. Experts and other advice-providers can assist the consumer by providing information about typical uses of the product, but they generally do not have information about an individual consumer's expected use patterns.

\subsubsection{Correction by Sellers}

In addition to learning by consumers, sellers may invest in correcting consumer misperceptions. ${ }^{17}$ Consider the following, arguably common, scenario. Seller A offers a product that is better and costs more to produce than the product offered by seller B. Consumers, however, underestimate the added value from seller A's product and thus refuse to pay the higher price that seller A charges. In this scenario, seller A has a powerful incentive to educate consumers about its product - to correct their underestimation of the product's value. Underestimation of value is often the product of a use-pattern mistake. For example, consumers who underestimate the intensity with which they will use a product will underestimate the value of a higher-quality, more resilient product. Accordingly, seller A will want to correct consumers' use-pattern mistake.

But what if both seller A and seller B and many other sellers offer identical lowquality products? If seller A increases the quality of its product and invests in correcting the use-pattern mistake that led consumers to undervalue high-quality products, then seller A will attract a lot of business and make a supra-competitive profit. But this is not an equilibrium. After seller A invests in consumer education, all the other sellers will free ride on seller A's efforts. They will similarly increase quality and compete away any profit that seller A would have made. Anticipating such a response, seller A will realise that, if it invests in consumer education, it will not be able to recoup its investment. It will thus choose not to increase the quality of its product, and instead will continue to offer a low-quality product. This collective action problem can lead to the persistence of consumer misperception. ${ }^{18}$

indicate to another: 'This is a good printer if you don't print more than 100 pages a month, otherwise it is expensive.' This information is useful to consumers with different use patterns. Interpersonal learning about use-pattern information is plausible if the 'teacher' conveys generic information that the 'learner' can adapt to his or her own circumstances.

16 See e.g. R.A. Epstein, 'Second-Order Rationality' in E.J. McCaffery and J. Slemrod (eds.), Behavioral Public Finance (2006) 355 at 361-362.

17 See e.g. Epstein, above note 13, at 120. The line between consumer learning and seller advertising is not always clear. Sellers can and do influence information transmission between consumers (word-of-mouth). See D.B. Godes and D. Mayzlin, 'Firm-Created Word-of-Mouth Communication: A Field-Based QuasiExperiment' (2004) Harvard Business School Marketing Research Paper No. 04-03.

${ }_{18}$ See H. Beales, R. Craswell and Steven Salop, 'The Efficient Regulation of Consumer Information' (1981) 24 J.L. and Econ. 491 at 527 (explaining why sellers might not disclose both positive and negative information). See also R. Ted Cruz and J.J. Hinck, 'Not My Brother's Keeper: The Inability of the Informed Minority to Correct for Imperfect Information' (1996) 47 Hastings L.J. 635 at 659. In some markets, the first-mover advantage will be large enough to overcome the collective action problem. Branding and product differentiation can also reduce the collective action problem. See Epstein, above note 13, at 120. But see Bar-Gill, above note 14, at § I.B. (identifying the limits of Epstein's branding and differentiation argument). In this sense, monopoly power, including limited monopoly power conferred by patent or trademark, by geographic proximity and so forth, can facilitate mistake correction by reducing the collective action problem. See Beales, Craswell and Salop, see above, at 503-509, for a general discussion of information failures in consumer markets. On the limits of advertising as a mistake-correction mechanism, see also X. Gabaix and D. Laibson, 'Shrouded Attributes, Consumer Myopia, and Information Suppression in Competitive Markets' (2006) 121 Q. J. Econ. 505; Korobkin, above note 11, at 1242-1243. 
Even apart from this collective action problem, sellers might prefer not to correct consumer mistakes and might even invest in creating misperception. Arguably, manipulation of consumer perceptions, and even preferences, is a main purpose of advertising. ${ }^{19}$ For example, to increase demand for their product, sellers will often try to persuade consumers that they will use a product more than they actually will. Therefore, while competing sellers may often choose to educate consumers, this mistake-correction force is limited.

Moreover, use-pattern mistakes are less susceptible to correction as compared to product attribute mistakes. Sellers have a powerful incentive to correct product attribute mistakes, and specifically to undo any underestimation of product quality, because these product attribute mistakes hurt the seller's reputation and thus adversely affect not only the demand for this one product but also the demand for the seller's other products. Since use-pattern mistakes do not have a similar effect on the seller's reputation, the incentive to correct such mistakes is weaker.

Finally, and most importantly, while sellers have powerful incentives to voluntarily disclose product attribute information, they do not have similar incentives to disclose product use information. First, consider the case of product attribute information. Rational but uninformed consumers, facing different sellers offering products of varying quality, would be willing to pay for only average quality. A seller with an above-average product would thus have a strong incentive to disclose the quality of its product (product attribute information). But this is not the end of the story. Since all above-average sellers disclose the quality of their products, consumers would know that any seller who remains silent is in the bottom half of the quality distribution. Consumers who face a silent seller would thus be willing to pay for only average quality in the bottom half of the quality distribution. A bottom-half seller whose product exceeds the average quality in the bottom half of the quality distribution would thus have a strong incentive to disclose the quality of its product. Now consumers would know that any seller who remains silent is in the bottom quarter of the quality distribution. This dynamic of disclosure and inference continues until all sellers, except for the lowest quality seller, disclose the quality of their products. ${ }^{20}$

Such voluntary disclosure is less likely with respect to product use information. Product-attribute information is seller-specific. Sellers disclose this information to attract buyers, by demonstrating that their product is superior to what their competitors are offering. Product-use information, on the other hand, is consumer-specific, at least in part. If a seller discloses product use information, there is no guarantee that the consumer will purchase the product from the disclosing seller. As long as the disclosed use patterns are common to the entire product category, i.e., they are not seller-specific, the nowinformed consumer may just as well purchase the product from a non-disclosing seller. Accordingly, sellers have little reason to voluntarily disclose use-pattern information. The standard argument for voluntary disclosure of product attribute information does not extend to product use information. ${ }^{21}$

\section{Disclosure Regulation}

Consumer mistakes are costly. Sellers' response to these mistakes often increases their cost. An identification of a market failure, here a behavioural market failure, opens

\footnotetext{
19 See E.L. Glaeser, 'Psychology and the Market' (2004) 94 Am. Econ. Rev. Papers and Proceedings 408 at 409-411 ('Markets do not eliminate (and often exacerbate) irrationality. ... The advertising industry is the most important economic example of these systematic attempts to mislead, where suppliers attempt to convince buyers that their products will yield remarkable benefits. ... It is certainly not true that competition ensures that false beliefs will be dissipated. Indeed in many cases competition will work to increase the supply of these falsehoods.'). Glaeser argues, however, that government decision-makers have weaker incentives than consumers to overcome errors, and thus intervention in markets might make things worse. Id. See also E.L. Glaeser, 'Paternalism and Psychology' (2006) 73 U. Chi. L. Rev. 133.

20 See S.J. Grossman and O.D. Hart, 'Disclosure Laws and Takeover Bids' (1980) 35 J. of Fin. 323.

${ }^{21}$ See O. Bar-Gill and O. Board, 'Product Use Information and the Limits of Voluntary Disclosure' (unpublished manuscript).
} 
the door to the possibility of welfare-enhancing legal intervention. In many markets the primary form of regulation is disclosure mandates. Disclosure is preferred because it does not constrain market forces. Instead it facilitates the efficient operation of markets. ${ }^{22}$ Disclosure mandates are perhaps the most widely used tool for regulating consumer products and contracts. Disclosure regulations are promulgated at both the federal and state levels. And disclosure requirements are based on both statutory law and common law.

Product attribute information features prominently in the vast landscape of disclosure regulation. A comprehensive survey of product attribute disclosure mandates is beyond the scope of this article. Yet even a few examples demonstrate the range of product attribute information that is subject to disclosure mandates. Starting with price information, the Truth in Lending Act (TILA) requires disclosure of interest rates and fees by lenders, ${ }^{23}$ and the same is true under EU law. ${ }^{24}$ TILA also mandates transparent disclosure of different price components as well as total price in consumer lease contracts. ${ }^{25}$ Parallel legislation, the Truth in Savings Act, requires depository institutions to disclose fees and other terms concerning deposit accounts. ${ }^{26}$ And regulations promulgated by the Securities and Exchange Commission require disclosure of mutual fund fees ${ }^{27}$ as does a very recent Proposal for a Directive of the European Parliament and of the Council on Alternative Investment Fund Managers. ${ }^{28}$ Mandated disclosure of price information is not limited to financial services. For example, the Real Estate Settlement Procedures Act requires disclosure of closing costs in real estate transactions ${ }^{29}$ And the Federal Trade Commission (FTC) requires various price disclosures in its Funeral Industry Practices Rule. $^{30}$

Moving on to product quality information, FTC trade regulations require gasoline stations to post octane ratings of gasoline, ${ }^{31}$ sellers of insulation to disclose the effectiveness of the insulation, ${ }^{32}$ sellers of home amplifiers to disclose the power output of the amplifier, ${ }^{33}$ and the list goes on. ${ }^{34}$ The Nutrition Labeling and Education Act, enforced by the Food and Drug Administration (FDA), directs that food labels list information concerning twelve of the most important nutrients. ${ }^{35}$ The FDA also regulates drug labelling. ${ }^{36}$ For example, labels of non-prescription, over-the-counter (OTC) drugs

22 Yet disclosure is not without cost. See below Section 3.6.

2315 United States Code [hereinafter U.S.C] § 1601 et seq.; 12 Code of Federal Regulations [hereinafter C.F.R] $§ 226$.

24 See Art. 5(1)(1) of EP and Council Directive 2008/48/EC, OJ L 133/66.

2512 C.F.R. \$ 213 . See also Press Release, Federal Reserve, available at: $<$ http://www.federalreserve.gov/ boarddocs/press/boardacts/1996/19960927/default.htm> (last visited 27 September 1996).

$26 \quad 12$ U.S.C. $\$ 4301$ et seq.; 12 C.F.R. $\$ 230(2000)$

27 Shareholder Reports and Quarterly Portfolio Disclosure of Registered Management Investment Companies, Exchange Act Release, 33-8393, 34-49333, IC-26372, File No. S7-51-02, 17 C.F.R. $\S \S 210$, 239, 249, 270 and 274; RIN 3235-AG64, 2004 SEC LEXIS 474.

28 See Art. 20(1)(h) of the EP and Council Proposal for a Directive of 30 April 2009, COM (2009) 207 final.

${ }_{29} 12$ U.S.C. $\S \S 2601-2617$; HUD, RESPA, available at: <http://www.hud.gov/offices/hsg/sfh/res/respa hm.cfm> (last visited 8 August 2007).

$30 \quad 16$ C.F.R $\S 453$ (especially $\S 453.2$ ). See also Federal Trade Commission, Facts for Business: Complying with the Funeral Rule (2004), available at: <http://www.ftc.gov/bcp/edu/pubs/business/adv/bus05.shtm>.

$31 \quad 16$ C.F.R. $\S 306.10$.

32 Id., at $\S \S 460.13-460.14$.

33 Id., $\S 432$.

34 For an exhaustive list of the disclosure rules that the FTC enforces, see P.C. Ward, Federal Trade Commission: Law, Practice and Procedure (2006). The FTC is also engaged in negative disclosure regulation, working to prevent disclosure of false or misleading information. The FTC has general authority to police unfair or deceptive acts or practices. See Federal Trade Commission Act, 15 U.S.C. $\S \S 41-58$. It also has authority under specific statutes such as the Nutrition Labeling and Education Act, which regulates health claims on food labels and in food product advertising. 21 U.S.C. $\S 301 ; 21$ C.F.R. § 101. See also: $<$ http://www.cfsan.fda.gov/label.html $>$ (last visited 12 March 2010). The FTC regulates food advertising, while the Food and Drug Administration (FDA) is responsible for food labelling. See Working Agreement Between the FTC and FDA, 3 Trade Reg. Rep. (CCH) P 9851 (1971).

3521 U.S.C. $\S 301 ; 21$ C.F.R. $\S 101$. See also: <http://www.cfsan.fda.gov/label.html>.

3621 U.S.C. $\$ 352$ (n); 21 C.F.R. § 201 (prescription drugs); 21 C.F.R. 201.66 (non-prescription drugs). The FDA supervises labelling of both prescription and non-prescription drugs. With respect to advertising, 
must provide information on active ingredients and on the purposes and uses of the drug. ${ }^{37}$ The Motor Vehicle Information and Cost Savings Act, enforced by the National Highway Traffic Safety Administration, requires car dealers to disclose information about a vehicle's damage susceptibility, crashworthiness and ease of diagnosis and repair. ${ }^{38}$ And the courts, enforcing contract law doctrine, require disclosure of material facts about any contractual transaction. ${ }^{39}$ Contract law also provides incentives for disclosure of contract terms ${ }^{40}$ which, given the collapse of the product-contract distinction, ${ }^{41}$ are also considered quality information. ${ }^{42}$

In Europe, too, disclosure of product quality information is required in many contexts. For example, pursuant to EU law, food labels must provide product quality information to consumers ${ }^{43}$ including mandatory front-of-pack nutrition information. ${ }^{44} \mathrm{EU}$ law also regulates drug labelling, requiring, for instance, that the packaging contain a statement of the active substances expressed qualitatively and quantitatively per dosage unit or

the FDA has the authority to supervise advertising for prescription drugs, while the FTC supervises nonprescription drug marketing. See Memorandum of Understanding Between Federal Trade Commission and the Food and Drug Administration, 36 Fed. Reg. 18539 (16 September 1971).

3721 C.F.R. § 201.66. See also FDA Center for Drug Evaluation and Research, 'OTC Labeling: Questions and Answers', available at: <http://www.fda.gov/cder/otc/label/quesanswers.htm> (last visited 8 August 2007).

38 15 U.S.C. $\S \S 1901-2012$.

39 See Restatement (Second) of Contracts $\S 161 \mathrm{~b}$ (1981) (unilateral mistake doctrine). See also R. Craswell, 'Taking Information Seriously: Misrepresentation and Nondisclosure in Contract Law and Elsewhere' (2006) 92 Va. L. Rev. 565 at 575 (discussing the duty to disclose product attributes and contract terms); M.A. Eisenberg, 'Disclosure in Contract Law' (2003) 91 Cal. L. Rev. 1645.

40 In particular, unconscionability doctrine provides an indirect incentive for sellers to inform consumers about contract terms. See Beales, Craswell and Salop, above note 18, at 493-494. See also Craswell, above note 39 , at 575 (discussing the duty to disclosure product attributes and contract terms.); Eisenberg, above note 39. In insurance law, the 'reasonable expectations' doctrine provides insurers with an incentive to disclose policy terms to consumers. See e.g. R.E. Keeton, 'Insurance Law Rights at Variance with Policy Provisions' (1970) 83 Harv. L. Rev. 961 at 968; D. Schwarcz, 'A Products Liability Theory for the Judicial Regulation of Insurance Policies’ (2007) 48 Wm. and Mary L. Rev. 1389 at 1395.

${ }_{41}$ See A.A. Leff, 'Contract as Thing' (1970) 19 Am. U. L. Rev. 131, 144-151 and 155; L.A. Kornhauser, 'Unconscionability in Standard Forms' (1976) 64 Cal. L. Rev. 1151; D.G. Baird, 'The Boilerplate Puzzle' (2006) 104 Mich. L. Rev. 933.

42 See also Magnuson-Moss Consumer Warranty Act, 15 U.S.C. $\S \S 2301-2312$ (requiring a seller or manufacturer who provides a written express warranty to properly disclose warranty or service contract terms). In addition, both federal and state law facilitates the meaningful disclosure of certain contract terms, especially warranty and liability-related terms, by requiring that they be conspicuously disclosed. See e.g. 15 U.S.C. $\S 2303$ (consumer product warranties must be labelled conspicuously); Uniform Commercial Code $\S 2-316(2)$ (any disclaimer of the implied warranty of merchantability must be conspicuously disclosed); New York Personal Property Law $§ 335.1$ (liability of an automobile lessee for the total loss of a vehicle must be conspicuously disclosed). See also J. Sovern, 'Toward a New Model of Consumer Protection' (2006) 47 Wm. \& Mary L. Rev. 1635 at 1688.

43 See most recently the EP and Council Proposal for a Regulation of 30 January 2008, COM (2008) 40 final; see also EP and Council Directive 2000/13/EC, OJ 2000 L 109/29 (Corrigendum to Directive 2000/13/EC, OJ 2000 L 124/66) as amended by EP and Council Directive 2003/89/EC, OJ 2003 L 308/15, and Commission Directive 2001/101/EC, OJ 2001 L 310/19, and Council Directive 2006/107/EC, OJ 2006 L 363/411, and Commission Directive 2006/142/EC, OJ 206 L 368/110, and Commission Directive 2007/68/EC, OJ 2007 L 310/11, and EP and Council Regulation (EC) No. 1332/2008, OJ 2008 L 354/7; Commission Directive 87/250/EEC, OJ 1987 L 113/57; Council Directive of 14 June 1989, OJ 1989 L 186/21, as amended by Council Directive 91/238/EEC, OJ 1991 L 107/50, and Council Directive 92/11/ EEC, OJ 1992 L 65/32; Commission Directive 94/54/EC, OJ 1994 L 300/14, as amended by Council Directive 96/21/EC, OJ 1996 L 88/5; EP and Council Regulation (EC) No. 1829/2003, OJ 2003 L 268/1, as amended by Commission Regulation (EC) No. 1981/2006, OJ 2006 L 368/99, and EP and Council Regulation (EC) No. 298/2008, OJ 2008 L 97/64; EP and Council Regulation (EC) No. 1830/2003, OJ 2003 L 311/1.

${ }_{44}$ Apart from some of the provisions contained in the statutory material referred to in the previous note, see Council Directive 90/496/EEC, OJ 1990 L 276/40, as amended by EP and Council Regulation (EC) No. 1882/2003, OJ 2003 L 284/1, and by the Commission Directive 2003/120/EC, OJ 2003 L 333/51, and Commission Directive 2008/100/EC, OJ 2008 L 285/9 (making nutrition labelling mandatory where a nutrition claim appears on labelling, in presentation or in advertising, with the exclusion of generic advertising). 
according to the form of administration for a given volume or weight. ${ }^{45}$ Also, like in the United States, disclosure of material facts relating to certain transactions is required in Europe, too. ${ }^{46}$ In effect, this duty to disclose constitutes a core principle ${ }^{47}$ of European contract law, as recently acknowledged by the drafters of the 2009 Draft Common Frame of Reference, which states that

[b]efore the conclusion of a contract for the supply of goods, other assets or services by a business to another person, the business has a duty to disclose to the other person such information concerning the goods, other assets or services to be supplied as the other person can reasonably expect, taking into account the standards of quality and performance which would be normal under the circumstances. ${ }^{48}$

Finally, like US law, European law as well provides incentives for disclosure of contract terms. ${ }^{49}$

The quality dimension that is most often subject to disclosure regulation is product risk. The Federal Hazardous Substances Act requires that certain hazardous household products bear cautionary labelling to alert consumers to the potential hazards that those products present.$^{50}$ FDA regulations require that OTC drug labels include warnings about possible side-effects and other risks associated with the use of the drug. ${ }^{51}$ Under regulations promulgated by the Environmental Protection Agency (EPA) and the Department of Housing and Urban Development (HUD), sellers, landlords and agents must disclose the use of lead-based paint on the property and provide purchasers and tenants with an EPA-approved lead hazard information pamphlet. ${ }^{52}$ And tort law, through its 'duty to warn', provides strong incentives for the disclosure of product risk information. In particular, the failure to provide a reasonable warning about a product risk is considered a product defect that might trigger tort liability. ${ }^{53}$

45 See e.g. EP and Council Directive 2001/83/EC, OJ 2001 L 311/67.

46 See e.g. Council Directive 85/577/EEC, OJ 1985 L 372/31; Council Directive 90/314/EEC, OJ 1990 L 158/59; EP and Council Directive 94/47/EC, OJ 1994 L 280/83 (recently amended by EP and Council Directive 2008/122/EC, OJ 2009 L 33/10, which set forth information duties as well); EP and Council Directive 97/7/EC, OJ 1997 L 144/19, as amended by EP and Council Directive 2002/65/EC, OJ 2002 L 271/16, and EP and Council Directive 2005/29/EC, OJ 2005 L 149/22, and EP and Council Directive 2007/64/EC, OJ 2007 L 319/1; EP and Council Directive 98/6/EC, OJ 1998 L 80/27; EP and Council Directive 2008/48/EC, OJ 2008 L 133/66.

${ }^{47}$ See e.g. P. Giliker, 'Regulating Contracting Behaviour: The Duty to Disclose in English and French Law' (2005) European Review of Private Law 621 at 622-623.

48 Draft Common Frame of Reference, Chapter II.-3:101(1) (2009). See also EP and Council Proposal for a Directive of 8 October 2008, COM (2008) 614 final (Chapters II and III).

49 See e.g. Council Directive 85/577/EEC, OJ L 372/31; EP and Council Directive 1999/44/EC, OJ L 171/12; Directive 2008/48/EC, OJ 2008 L 133/66; EP and Council Proposal for a Directive of 8 October 2008, COM (2008) 614 final.

50 15 U.S.C. $\S \S 1261-1278 ; 16$ C.F.R. $\S \S 1500-1512$. See also U.S. Consumer Products Safety Commission, Federal Hazardous Substances Act, available at: <http://www.cpsc.gov/businfo/fhsa.html $>$ (last visited 12 March 2010). Among the disclosures that such labels must include are: the name and business address of the manufacturer, packer, distributor or seller; the common or usual or chemical name of each hazardous ingredient; the signal word 'Danger' for products that are corrosive, extremely flammable or highly toxic; the signal word 'Caution' or 'Warning' for all other hazardous products; an affirmative statement of the principal hazard or hazards that the product presents, for example, 'Flammable', 'Harmful if Swallowed', 'Causes Burns', 'Vapor Harmful', etc.; the word 'Poison' for a product that is highly toxic, in addition to the signal word 'Danger'. See Office of Compliance, Consumer Product Safety Commission, Requirements under the Federal Hazardous Substances Act: Labeling and Banning Requirements for Chemicals and Other Hazardous Substances (2002) at 3, available at: <http://www.cpsc.gov/businfo/regsumfhsa.pdf $>$.

5121 C.F.R. $§ 201.66$ (c) (warnings for non-prescription drugs, including side-effects).

52 See Residential Lead-Based Paint Hazard Reduction Act of 1992, 42 U.S.C. $\S \S 2681-2692,4851-4856$; Requirements for Disclosure of Known Lead-Based Paint and/or Lead-Based Paint Hazards in Housing, 24 C.F.R. § 35, 40 C.F.R. § 745. See also Toxic Substances Control Act, 15 U.S.C. § 2686.

53 See Restatement (Third) of Torts: Product Liability § 2 (1998); W. Page Keeton et al., Prosser and Keeton on the Law of Torts (1988) at 96; Craswell, above note 39, at 566; J.A. Henderson, Jr. and A.D. Twerski, 'Doctrinal Collapse in Products Liability: The Empty Shell of Failure to Warn' (1990) 65 N.Y.U. L. Rev. 265; Latin, above note 11; J.D. Hanson and D.A. Kysar, 'Taking Behaviorism Seriously: The Problem of Market Manipulation' (1999) 74 N.Y.U. L. Rev 630. Accordingly, the Restatement (Third) of Torts: Products Liability instructs sellers to "provide reasonable instructions and warnings about risks of injury posed by products'. See Restatement (Third) of Torts: Products Liability $§ 2$, cmt. i (1998). See also Liriano v. Hobart Corp., 170 F.3d 264 (1999). 
In Europe, one of the most famous examples of required product risk disclosure relates to tobacco products. Pursuant to EU law, the use of warnings (both a general one - 'smoke kills/can kill' - and an additional one that must cover no less than $40 \%$ of the external surface of the packet) is compulsory. ${ }^{54}$ Of course, many more examples can be given. The packaging of paints or varnishes containing lead in quantities above a certain amount must disclose that the paints and varnishes contain lead. ${ }^{55}$ Similarly, the packaging of medicinal products must provide product risk information, such as information regarding the product's effects on the ability to drive and to use machines. ${ }^{56}$

The preceding examples demonstrate the prevalence of product attribute disclosures. Information about product attributes is clearly valuable. It is important to know what APR is charged on a credit card balance. It is important to know that orange juice contains vitamin C. And it is important to know that the paint in an apartment contains lead. With most products, however, the benefit or cost to a consumer from any product attribute depends on how the consumer will use the product. The APR on a credit card is more important for consumers who borrow more. Drinking orange juice is a good source of vitamin C, but only if the juice is consumed soon after the container is first opened. And lead paint is especially dangerous when chewed on by toddlers. Accordingly, if consumers make mistakes not only with regard to product attributes but also with regard to product use, it is important to provide use-pattern information in addition to product attribute information.

While many disclosure mandates focus on product attribute information, product use disclosure is not absent from the current regulatory scheme. Still, current use-pattern disclosures are insufficient - both in quantity and in quality. We begin by surveying existing use-pattern disclosure mandates in Sections 3.1 and 3.2. Existing product use disclosures fall into two categories: (1) proper-use disclosures; and (2) average-use information that is indirectly disclosed as a benchmark for product attribute disclosures. This survey of existing product use disclosures highlights the limits of the current regulatory scheme. We respond to these limits by advocating improved use-pattern disclosure. In Section 3.3, we argue for direct average-use disclosures. And, more importantly, in Section 3.4, we argue for the disclosure of individualised use-pattern information. After arguing that use-pattern information should be disclosed, we turn in Section 3.5 to the regulatory design question: how should use-pattern information be disclosed? Finally, Section 3.6 recalls the main costs and limits of disclosure regulation. The limited efficacy of disclosure and the costs of disclosure regulation caution against a broad expansion of the disclosure landscape. We do not argue for more disclosure. Rather, we argue for a more balanced division of disclosure mandates between product attribute information and use-pattern information and for better-designed use-pattern disclosures. ${ }^{57}$

\subsection{Proper-Use Information}

Use information is provided through disclosures that specify the proper use of a product. The Consumer Products Safety Commission (CPSC) has general authority to promulgate 'requirements that a consumer product be marked with or accompanied by clear and adequate warnings or instructions, ${ }^{58}$ The purpose of this provision is to provide information on how to use the product properly. Under this authority, the

54 See EP and Council Directive 2001/37/EC, OJ 2001 L 194/26.

55 See Commission Directive 2006/8/EC, OJ 2006 L 19/12.

56 See EP and Council Directive 2001/83/EC, OJ 2001 L 311/67.

57 An important question that we do not address in this article is the question of who should be entrusted with designing and enforcing disclosure regulations. One of us begins to address this question in the context of consumer credit products in O. Bar-Gill and E. Warren, 'Making Credit Safer' (2008) 157 U. PA. L. Rev. 1 (arguing that regulation of consumer credit markets, including disclosure regulation, should be entrusted to a federal administrative agency). See also A. Schwartz and L. Wilde, 'Intervening in Markets on the Basis of Imperfect Information: A Legal and Economic Analysis' (1979) 127 U. Pa. L. Rev. 630, 678-682 (arguing that administrative agencies are better suited than courts to address the market failure); Craswell, above note 39, at 700 (same); Ford Motor Credit Co. v. Mihollin, 444 U.S. 555, 568-569 (1980).

$58 \quad 15$ U.S.C. $\S 2056$ (emphasis added). 
CPSC has issued regulations requiring the disclosure of proper-use information for numerous products. ${ }^{59}$ For example, sellers of bicycle helmets must provide instructions telling riders how to make sure the helmet fits properly and how to wear it properly. ${ }^{60}$ Sellers of television antennas must provide instructions on how to avoid the hazard of electrocution during the installation of the antenna ${ }^{61}$ And sellers of bunk beds must provide instructions for safe use, including: 'Do not allow children under 6 years of age to use the upper bunk'; 'Use guardrails on both sides of the upper bunk'; 'Prohibit horseplay on or under beds'; 'Prohibit more than one person on upper bunk'; and 'Use ladder for entering or leaving upper bunk' ${ }^{62}$

The CPSC-enforced, Federal Hazardous Substances Act provides another example. The Act requires that certain hazardous household products bear cautionary labelling to alert consumers to the potential hazards that those products present and to inform them of the measures they need to take to protect themselves from those hazards. ${ }^{63}$ Specifically, such labels must include the following disclosures: precautionary statements telling users what they must do or what actions they must avoid to protect themselves; instructions for first aid treatment to perform in the event that the product injures someone; if a product requires special care in handling or storage, instructions for consumers to follow in order to protect themselves; and the statement 'Keep out of the reach of children'. ${ }^{64}$

The FTC, in its trade regulations, also requires disclosure of proper-use information. For example, the FTC requires clothing manufacturers to provide information on proper care. ${ }^{65}$ The FDA requires disclosure of proper-use information on drug labels. In particular, drug manufacturers must provide dosage and other proper-use information for non-prescription drugs. ${ }^{66}$ Moving on to real estate, the EPA and HUD require sellers, landlords and agents to provide purchasers and tenants with an EPA-approved lead hazard information pamphlet, which contains proper-use information on ways to minimise lead-based paint hazards. ${ }^{67}$

\footnotetext{
59 Beyond the examples provided below, CPSC regulations are listed on the CPSC's website, available at: $<$ http://www.cpsc.gov/cgi-bin/regs.aspx> (last visited 12 March 2010).

${ }_{60}$ See Office of Compliance, Consumer Product Safety Commission, Requirements for Bicycle Helmets (2002) at 4, available at: <http://www.cpsc.gov/businfo/regsumbicyclehelmets.pdf>.

$61 \quad 16$ C.F.R. $\S 1402$ ( $\$ 1402.1$ describes the scope of the regulation; $\$ 1402.4$ requires the disclosure of a specific warning: 'Warning: Installation of this Product Near Powerlines is Dangerous. For Your Safety, Follow the Installation Directions.').

${ }_{62}$ See CPSR Safety Standard for Bunk Beds, 16 C.F.R. $\S \S 1213,1500,1513$. See also Office of Compliance, Consumer Product Safety Commission, Safety Standard for Bunk Beds (2001) at 2, available at: $<$ http://www.cpsc.gov/businfo/regsumbunkbed.pdf $>$.

6315 U.S.C. $\S \S 1261-1278 ; 16$ C.F.R. $\S \S 1500-1512$. See also CPSC, Federal Hazardous Substances Act, available at: $<$ http://www.cpsc.gov/businfo/fhsa.html $>$ (last visited 8 August 2007).

${ }^{64}$ See Office of Compliance, Consumer Product Safety Commission, Requirements under the Federal Hazardous Substances Act: Labeling and Banning Requirements for Chemicals and Other Hazardous Substances (2002) at 3, available at: <http://www.cpsc.gov/businfo/regsumfhsa.pdf $>$.

${ }_{65}$ FTC Trade Regulation Rule: Care Labeling of Textile Wearing Apparel, 16 C.F.R. $\S 423$ (1980). See also EP and Council Working document on the proposal for a regulation of 8 April 2009, COM (2009) 31 final (stating that ' $[\mathrm{t}]$ here is currently no EU-wide legislation on care labeling, i.e. information on washing and ironing conditions'. But noting that ' $[\mathrm{s}]$ ome Member States have introduced national provisions for compulsory care labelling', and that 'most manufacturers include this kind of information on the label of the textile product on a voluntary basis').

6621 U.S.C. $\S 352$ (n); 21 C.F.R. § 201.66 (c). See also Food and Drug Administration, Drug Interactions: What You Should Know (2004), available at: <http://www.fda.gov/Drugs/ResourcesForYou/ucm163354 htm> ('The "Directions" section of the [over-the-counter drug] label tells you: the length of time and the amount of the product that you may safely use' and 'any special instructions on how to use the product'). For general information on the regulation of over-the-counter drugs, see: $<$ http://www.fda.gov/cder/offices/ otc/default.htm $>$ (last visited 12 March 2010)). Disclosure of dosage and other proper-use information is also required on prescription drug labels. See 21 C.F.R. § 201.5. See also FDA Requirements on Content and Format of Labeling for Human Prescription Drug and Biological Products, 21 C.F.R. $\S \S 201,314,601$. But this information is mainly for healthcare professionals, not consumers.

${ }_{67}$ HUD Requirements for Disclosure of Known Lead-Based Paint and/or Lead-Based Paint Hazards upon Sale or Lease of Residential Property, 24 C.F.R. § 35.8; EPA Requirements on Lead-Based Poisoning Prevention in Certain Residential Structures, 40 C.F.R. § 745; EPA, 'Protect Your Family from Lead in Your Home', available at: < http://www.epa.gov/lead/pubs/leadpdfe.pdf> (last visited 12 March 2010).
} 
And tort law, through its 'duty to warn', provides strong incentives for the disclosure of proper-use information. As mentioned above, the failure to provide reasonable instructions and warnings is considered a product defect. ${ }^{68}$ And on the flip side, adequate warnings often provide an effective shield against liability. ${ }^{69}$ The subject of these instructions and warnings is commonly proper-use information. ${ }^{70}$ As emphasised by Judge Calabresi in Liriano v. Hobart Corp., ${ }^{71}$ a warning does more than provide information about a product's dangerousness - product attribute information; it also provides information about how the product should be used - product use information.

Proper-use information is also publicised by government agencies. The CPSC's public information disclosures include safety suggestions, i.e. suggestions on how to use products safely. ${ }^{72}$ For example, the CPSC's website includes an Extension Cords Fact Sheet with suggestions on how to avoid risks associated with extension cords. ${ }^{73}$ Similarly, the FTC publicises information on the proper use of different products and services, including credit cards and automobiles. ${ }^{74}$ The SEC provides information on the proper use of investment products. For example, it emphasises the importance of diversification. ${ }^{75}$ And the FDA publicises information on the proper use of food and drug products. ${ }^{76}$

In Europe, as well, many products must be marked with, or accompanied by, clear and adequate instructions. For instance, where skates, roller skates, online skates,

\footnotetext{
${ }_{68} \quad$ See above note 53 .

69 Tort law often exempts manufacturers from liability whenever the harm could be avoided had the consumer followed the warning. See Restatement (Second) of Torts, § 402A, cmt. j (1965) ('Where [adequate] warning is given, the seller may reasonably assume that it will be read and heeded; and a product bearing such a warning, which is safe for use if it is followed, is not in defective condition, nor is it unreasonably dangerous.'); Ellsworth v. Sherne Lingerie, Inc., 495 A.2d 348, 356 (Md. 1985), note 12 ('If a product otherwise unreasonably dangerous can be made safe for reasonably foreseeable uses by adequate warnings or instructions, liability will be avoided, and the focus in such cases is generally on the adequacy of the notice. If the warnings or instructions are adequate the product is not defective, and the plaintiff cannot recover under a theory of strict liability in tort. The cause of the injury in such cases is the failure to read or follow the adequate warnings or instructions, and not a defective product.'). See also Latin, above note 11, at 1258 (describing and criticising Section 402A, Comment J, and other tort doctrines, like proximate cause and the unforeseeable misuse defence, that have been used to exempt manufacturers from liability based on warnings). The Restatement (Third) of Torts: Products Liability takes a less extreme approach but still counts the existence of a warning as a relevant consideration in establishing liability. See Restatement (Third) of Torts: Product Liability § 2, cmt. f (1998) (listing instructions and warranties accompanying the product as a relevant factor 'in determining whether an alternative design is reasonable and whether its omission renders a product not reasonably safe').

70 See Restatement (Third) of Torts: Product Liability $§ 2$, cmt. i (1998) ('Commercial product sellers must provide reasonable instructions and warnings about risks of injury posed by products. Instructions inform persons how to use and consume products safely.'). In fact, tort law often allows manufacturers to get away with an unsafe product design as long as they provide proper-use warnings. For example, the manufacturer of a toy BB-gun with lethal power was able to avoid liability by including a warning that the gun should not be pointed at any person. And the manufacturer of a lawnmower with inadequate protective skirts was able to avoid liability by including a warning that the lawnmower should not be operated when any person (other than the operator) is in its vicinity. See Latin, above note 11, at 1195-1196 (citing Sherk v. Daisy-Heddon, 450 A.2d 615 (Pa. 1982) (BB-gun case) and Dugan v. Sears, Roebuck \& Co., 454 N.E.2d 64 (1983) (lawnmower case)).

71 Liriano v. Hobart Corp., 170 F.3d 264, 270-271 (1999). See also J.A. Henderson, Jr. and A.D. Twerski, 'Doctrinal Collapse in Products Liability: The Empty Shell of Failure to Warn' (1990) 65 N.Y.U. L. Rev. 265,285 .

7215 U.S.C. $\S \S 2054-2055$ (the CPSC can collect and disclose information on product risks).

73 See CPSC Extension Cords Fact Sheet, CPSC Document No. 16, available at: <http://www.cpsc.gov/ cpscpub/pubs/16.html> (last visited 13 March 2010) (on extension cords).

74 See: $<$ http://www.ftc.gov/bcp/consumer.shtm> (last visited 13 March 2010).

75 SEC Beginners' Guide to Asset Allocation, Diversification, and Rebalancing, available at: <http:// www.sec.gov/investor/pubs/assetallocation.htm> (last visited 13 March 2010).

76 See FDA Consumer Advice and Publications on Food Safety, Nutrition, and Cosmetics, available at: $<$ http://www.cfsan.fda.gov/ /rd/advice.html > (last visited 9 August 2007). For information on the proper use of drugs/medicine, see FDA Consumer Education/Information, available at: $<\mathrm{http}$ :/www.fda.gov/cder/ drug/DrugSafety/drugSafetyConsumer.htm $>$ (last visited 9 August 2007); FDA Consumer Information: Safe Use of Over-the-Counter Drug Products, available at: <http:/www.fda.gov/cder/offices/otc/consumer $\mathrm{htm}>$ (last visited 9 August 2007).
} 
skateboards, scooters and toy bicycles for children are offered for sale as toys, they must bear the warning 'Protective equipment should be worn. Not to be used in traffic." ${ }^{\text {"7 }}$ More generally, EU law expressly requires that toys be accompanied by 'instructions ... which ... shall draw the attention of users or their supervisors to the inherent hazards and risks of harm involved in using the toys, and to the ways of avoiding such hazards and risks. ${ }^{78}$ Medicinal products, too, must be accompanied by

the necessary and usual instructions for proper use, in particular: the dosage, the method and, if necessary, route of administration, the frequency of administration, specifying if necessary, the appropriate time at which the medicinal product may or must be administered, and, as appropriate, depending on the nature of the product: the duration of treatment, where it should be limited, the action to be taken in the case of an overdose (e.g., symptoms, emergency procedures), the course of action to take when one or more doses have not been taken, indication, if necessary, of the risk of withdrawal effects. ${ }^{79}$

Disclosure of proper-use information is clearly important. But proper-use information also suffers from an important limitation. Although it is appropriate for use dimensions that have a single, well-defined proper use, not all use dimensions have a single, welldefined proper use. There is one proper way to wash a pair of jeans. There is no single, well-defined way to use a credit card. ${ }^{80}$ When proper use is not well defined, and even when it is well defined, sellers can disclose another type of product use information actual-use information. We next consider statistical actual-use information, i.e. averageuse or typical-use information.

\subsection{Product-Attribute Information with Average-Use Benchmarking}

Use-pattern information is sometimes provided indirectly through product attribute disclosures. We have argued that product use depends on product attributes. ${ }^{81}$ But product attributes can also depend on product use. For example, the fuel efficiency of an automobile depends on technical features of the vehicle and on how the vehicle is driven, e.g. city driving versus highway driving. A pure product attribute disclosure would include only technical information on the car's engine, weight and so forth. Most consumers will find it difficult to effectively use such a disclosure when choosing among different cars. Alternatively, the law may prefer a more comprehensible 'impure' product attribute disclosure that presumes a certain use pattern. For example, automobile manufacturers can be required to disclose miles-per-gallon information that necessarily presumes specific driving behaviour. Indeed, mandated disclosures sometimes assume, explicitly or implicitly, a certain use pattern and provide information on price, quality or risk based on this use pattern. ${ }^{82}$

Elaborating on the fuel efficiency example, expenditures on gasoline are a major cost of car ownership. As noted above, these expenditures are a function of a vehicle's inherent fuel efficiency and its owner's use patterns. The EPA decided that the best way to communicate gasoline cost information is through miles-per-gallon disclosures. Of course, the same vehicle will drive 10 miles-per-gallon under certain conditions and 20 miles-per-gallon under different conditions. The EPA chose two use patterns, 'city driving' and 'highway driving', and provided miles-per-gallon ratings for these two uses. Obviously, most consumers drive both in the city and on the highway and they divide their driving between these two uses in different proportions. Moreover, there is more than one way to drive in a city and more than one way to drive on the highway. But some benchmark had to be chosen. ${ }^{83}$

77 See EP and Council Directive 2009/48/EC, OJ 2009 L 170/1.

78 See Art. 10(2) of EP and Council Directive 2009/48/EC, OJ 2009 L 170/1.

79 Art. 59(1)(d) of EP and Council Directive 2001/83/EC, OJ 2001 L 311/67.

80 General statements like 'Do not borrow too much' or 'Use your card prudently' will not be very helpful.

81 See above Part 2.

82 To take a banal example, disclosure requirements under the Federal Hazardous Substances Act include the warning: 'Harmful if Swallowed'. See 15 U.S.C. § 1261; 16 C.F.R. § 1500; Consumer Product Safety Commission, Office of Compliance, Labeling and Banning Requirements for Chemicals and Other Hazardous Substances (2002) at 3, available at: $<$ http://www.cpsc.gov/businfo/regsumfhsa.pdf $>$ (US law); EP and Council Regulation (EC) No. 1272/2008, OJ 2008 L 353/1 (EU law).

${ }_{83}$ Energy Policy and Conservation Act, 42 U.S.C. § 6201. See also Craswell, above note 39, at 581-582 
Similarly, in the European Union, fuel consumption is generally expressed in either litres per 100 kilometres $(1 / 100 \mathrm{~km})$ or kilometres per litre $(\mathrm{km} / \mathrm{l}) .{ }^{84}$ Moreover, EU law expressly recognises the importance of different use patterns. Directive 1999/94/EC of the European Parliament and of the Council of 13 December 1999 relating to the availability of consumer information on fuel economy and $\mathrm{CO} 2$ emissions in respect of the marketing of new passenger cars requires that fuel economy labels for new passenger cars state: 'driving behaviour as well as other non-technical factors play a role in determining a car's fuel consumption' ${ }^{85}$

The energy efficiency feature of home appliances is similarly disclosed using a typical-use benchmark. A major cost of home appliances is energy cost. The energy cost depends on product attributes, i.e. on the technical features of the appliance, and on the consumer's use patterns. The FTC has constructed an energy efficiency index for appliances based on typical use and requires manufacturers to disclose their product's 'Energy Efficiency Rating' ${ }^{86}$

Nutrition information listed on food labels provides another example. The Nutrition Labeling and Education Act requires disclosure, on food product labels, of the quantities of twelve important nutrients. ${ }^{87}$ The quantity of a nutrient is pure product attribute information. But the health benefits or risks of a product do not depend only on this quantity measure. Use-pattern information, specifically how much one consumes of this and other food products, is as important as the quantity of nutrients per 100 grams. And food labels do include some indirect information on product use. Specifically, labels provide information on the quantity of nutrients per serving. The assumption is that the average consumer consumes one serving (or, alternatively, that the per-serving information will be used by the consumer to calculate total value). Food labels also provide 'percent daily value' information for the included nutrients. Percent daily value information depends not only on how much one consumes of the particular product but also on the consumer's overall diet. Food product manufacturers must include the statement 'Percent Daily Values are based on a 2,000 calorie diet'. And, in some cases, a more detailed disclosure of daily values based on both a 2,000-calorie and a 2,500 -calorie diet is required. ${ }^{88}$

Required disclosure of the risks associated with cigarette smoking also makes certain assumptions about use patterns. We focus on the US Surgeon General's warnings that appear on cigarette labels and advertisements, ${ }^{89}$ although similar warnings are required in Europe ${ }^{90}$ One warning reads: 'Smoking Causes Lung Cancer, Heart Disease, and May Complicate Pregnancy.' Another reads: 'Quitting Smoking Now Greatly Reduces Serious Risks to Your Health.' And a third reads: 'Smoking by Pregnant Women May Result in Fetal Injury, Premature Birth, and Low Birth Weight.' The risks of smoking

("the EPA publishes only two indices of automobile gasoline consumption ("city" and "highway" milesper-gallon ratings), each of which is a rough attempt to reflect the driving habits of millions of different drivers.').

${ }^{84}$ See EP and Council Directive 1999/94/EC, OJ 2000 L 1216.

85 Id., at Annex I(6).

86 16 C.F.R. § 305 (Rule Concerning Disclosures Regarding Energy Consumption and Water Use of Certain Home Appliances and Other Products Required under the Energy Policy and Conservation Act - 'Appliance Labeling Rule'). See also Craswell, above note 39, at 581-582 ('the energy used by a home appliance will vary depending on consumers' usage patterns, and the actual cost of that energy will also vary depending on local electricity rates. It might have been possible to present this data in a complicated table, so that consumers could use their own electric bills (and their knowledge of their own usage patterns) to estimate their energy costs with some precision. However, the FTC believed that few consumers had the time or the patience to calculate their actual costs in this way, so it constructed its own index of likely energy costs which allowed the costs of different appliances (relative to other appliances of the same type) to be disclosed in the form of a single "Energy Efficiency Rating".).

$87 \quad 21$ U.S.C. $\$ 301$.

8821 C.F.R. $\$ 101.9(\mathrm{~d})(9)$.

89 The Comprehensive Smoking Education Act, 15 U.S.C. $\S 1331-1341$.

90 See Directive 2001/37/EC of the European Parliament and of the Council of 5 June 2001 on the approximation of the laws, regulations and administrative provisions of the Member States concerning the manufacture, presentation and sale of tobacco products. 
depend on the number of cigarettes smoked. The risk from smoking one cigarette a month is not equal to the risk of smoking two packs a day. The Surgeon General's warnings implicitly assume that most smokers smoke more than one cigarette a month.

These Surgeon General's warnings are required by law. But tobacco companies voluntarily provide additional information about the risks of smoking. Specifically they provide information about the levels of tar and nicotine produced by the cigarette. This information, while voluntarily disclosed, is certified by the FTC. Tar and nicotine levels depend on product attributes as well as on use patterns. The FTC developed a machinebased test to objectively measure tar and nicotine levels, and the tar and nicotine measures provided by the FTC test assume a certain intensity of smoking - a 2-second, 35-milliliter puff every minute. ${ }^{91}$ It is now understood that the FTC's machine-based test does not reflect any reasonable assumption about typical smoking behaviour. ${ }^{92}$ First, the machine-based FTC test has been shown to only poorly represent actual smoking by humans ${ }^{93}$ Second, if a cigarette provides less nicotine and less tar per puff, smokers will compensate by taking deeper, longer or more frequent puffs from their cigarettes, ${ }^{94}$ or simply by smoking more cigarettes, i.e. by changing their use patterns. ${ }^{95}$ The FTC rating ignores the critical impact of such compensation.

Cigarette manufacturers use the FTC's nicotine and tar ratings to promote 'low tar' and 'light' cigarettes. ${ }^{96}$ Moreover, a 1981 Surgeon General's report encouraged smokers who are unable to quit to switch to cigarettes that scored better on the FTC rating. ${ }^{97}$ These inducements worked. Some $85 \%$ of all smokers today use the supposedly safer cigarettes. ${ }^{98}$ But it is now clear that these cigarettes are not safer, because of the compensation effect.9 ${ }^{99}$ The FTC recognised the importance of use patterns and how the compensation effect limits the informative value of its nicotine and tar ratings. A consumer alert published by the FTC emphasises the importance of use patterns:

The Federal Trade Commission wants you to know that cigarette tar and nicotine ratings can't predict the amount of tar and nicotine you get from any particular cigarette. That's because how you smoke a cigarette can significantly affect the amount of tar, nicotine, and carbon monoxide you get from your cigarette. ${ }^{100}$

The FTC even proposed required disclosures that emphasise use patterns. The two alternative disclosures proposed by the FTC were:

FTC News Release, 'FTC Proposes New Method for Testing Amounts of Tar, Nicotine, and Carbon Monoxide in Cigarettes: New System Will Provide Consumers With Improved Info. About Cigarette Tar and Nicotine Yields', 9 September 1997 [hereinafter FTC News Release]. The FTC proposed to make disclosed tar and nicotine levels more informative by adding a second, high-intensity rating, based on a 2 -second, 55-milliliter puff every 30 seconds. Id. The FTC ratings are voluntarily disclosed by the major cigarette companies in all cigarette advertisements. Id. In particular, these ratings are used to promote 'low tar' and 'light' cigarettes. See e.g. Advertisement for Merit, Merit Low Tar Kings Soft, Merit Ultima Kings Soft and Merit Ultra Lights Kings Soft, 'Now you're on the road. You've got Merit', Philip Morris USA Advertising Archive, Document ID 2061038984, available at: $<$ http://www.pmadarchive.com $>$ (last visited 13 March 2010 [hereinafter Merit Advertisement].

92 See also J. Foulds et al., 'Health Effects of Tobacco, Nicotine, and Exposure to Tobacco Smoke Pollution' in J. Brick (ed.), Handbook of the Medical Consequences of Alcohol and Drug Abuse (2008) 423 at 435 et seq.

${ }_{93}$ See FTC Consumer Alert, 'Up in Smoke: The Truth About Tar and Nicotine Ratings' (May 2000) [hereinafter FTC Consumer Alert] ('people don't smoke cigarettes the same way the machine does'); Editorial, 'The Safer Cigarette Delusion', N.Y. Times, 28 August 2006, at A14 [hereinafter The Safer Cigarette Delusion]

94 See Foulds et al., above note 92, at 437.

95 See FTC Consumer Alert, above note 93; FTC News Release, above note 91; U.S. v. Philip Morris USA, Inc., 449 F.Supp.2d 1, 337-338 (D.D.C., 2006); The Safer Cigarette Delusion, at A14 ('More than 95 percent of all smokers compensate, with many replacing every bit of tar and nicotine they thought they were avoiding.').

96 See e.g. Merit Advertisement, above note 91.

97 The Safer Cigarette Delusion, at A14.

98 Id.

99 See also Foulds et al., above note 92 , at 438.

100 See FTC Consumer Alert, above note 93. 
1) There's no such thing as a safe smoke. Even cigarettes with low ratings can give you high amounts of tar and nicotine. It depends on how you smoke; or

2) How much tar and nicotine you get from a cigarette depends on how intensely you smoke it. ${ }^{101}$

These proposals were not implemented. ${ }^{102}$ The tar and nicotine disclosures described above demonstrate the importance of choosing accurate typical-use assumptions. Inadequate provision of use-pattern information renders the product attribute information meaningless, even misleading. Of course, product attribute disclosure based on accurate typical-use benchmarking can be helpful.

\subsection{Direct Disclosure of Average-Use Information}

The previous section provides examples of average-use information indirectly disclosed as a benchmark for product attribute disclosures. While average-use information is helpful even when it is disclosed indirectly, in some markets lawmakers should consider mandating direct disclosure of average-use information. For example, there is evidence suggesting that consumers are too quick to purchase extended warranties and other insurance riders that are commonly offered as add-ons with basic consumer products. The small likelihood of an event that would trigger the warranty or insurance coverage, coupled with the relatively small cost that the consumer would bear if such an event occurs, cannot justify the price of the add-on. One possible remedy for this category of mistakes - overestimation of the value of the insurance product - is to provide usepattern information. As suggested by Professors Ian Ayres and Barry Nalebuff, sellers could be required to provide information on the probability that an extended warranty would be invoked. ${ }^{103}$ Or, even better, sellers could be required to provide an estimate of the total repair or replacement costs that a typical consumer would save by purchasing the extended warranty. With this use-pattern information, extended warranties and similar insurance add-ons would likely suffer a sharp decline in sales. ${ }^{104}$

In the rebates context, Jeff Sovern has recently proposed that sellers offering rebates be required to disclose the low redemption rates. ${ }^{105}$ Similarly, if Blockbuster's customers underestimate the likelihood, and hence the cost, of tardiness in returning their video rentals, then Blockbuster could be required to disclose the number of late returns and the total fee payments that an average consumer pays over a one-year period. If HewlettPackard (HP) customers, when purchasing a home printer, underestimate the number of ink cartridges that they will purchase over the life of the printer, then HP can be required to provide the missing use-pattern information, perhaps based on an FTCdesigned average-use index. Even better, HP could be required to disclose average Total Cost of Ownership (TCO) information that combines the use-pattern information with ink prices. Similar average-use or total price information could be provided by sellers of base goods and add-ons bundles. With such information, for example, a consumer choosing between two hotels could compare not only room rates but also total price figures, based on an average add-on use index (e.g. two phone- calls, one in-room meal, one movie, etc.). And health clubs could be required to disclose the effective per-visit

\footnotetext{
101 FTC News Release, above note 91.

102 See 15 U.S.C.A. § 1333 (specifying the required disclosures); 15 U.S.C.A. § 1334 (preemption - 'No statement relating to smoking and health, other than the statement required by section 1333 of this title, shall be required on any cigarette package.').

103 See B. Nalebuff and I. Ayres, Why Not? (2003) at 181 ('Circuit City or Ford could tell you the odds of actually making a claim against an extended warranty.'). See also I. Ayres, Super Crunchers (2007).

104 Interestingly, use-pattern information for the insurance add-on is a function of both product attribute information and product use information for the base good. For example, the likelihood that an extended warranty will be invoked depends on the reliability of the base good and on how the base good is used.

105 See Sovern, above note 42, at 1703. See also J.G. Lynch and G. Zauberman, 'When Do You Want It? Time, Decisions, and Public Policy' (2006) 25 J. Public Policy and Marketing 67 at 71 (making a similar proposal).
} 
fee paid by an average subscription holder. If this effective per-visit fee is eight times higher than the club's actual per-visit fee, some consumers may reconsider their decision to purchase a subscription. ${ }^{106}$

Direct average-use disclosures could also be effective in the credit card market. Some consumers are sometimes late in paying their credit card bill. And when they are late, they are assessed a 'late fee'. This late fee is prominently disclosed in credit card solicitations, in accordance with the disclosure regulations issued under the Truth in Lending Act (TILA). ${ }^{107}$ But this product attribute disclosure will not be very effective if consumers underestimate the likelihood of paying late. TILA disclosures, especially disclosures in card solicitations, are supposed to help consumers make an informed choice among the many competing credit card products. Such informed choice is crucial for the efficient operation of the credit card market. A consumer who underestimates the likelihood of paying late and triggering a late fee will not make a truly informed choice, even if he or she has perfect information about the magnitude of the late fee. The TILA disclosure apparatus can and should be amended to include use-pattern disclosures. Specifically, issuers can be required to disclose the number of late payments that an average consumer makes in a year or the amount that an average consumer pays in late fees in one year.

Moving from late payments to debt repayment rates, a recent amendment to the Truth in Lending Act requires issuers to provide average-use information. Congress was concerned that consumers lack information on the cost of slow repayment. Specifically, many consumers who make only the minimum monthly payment underestimate the amount of time that it will take them to repay their credit card debt and, consequently, underestimate the total amount of interest that they will end up paying. In response, Congress required issuers to disclose on the monthly statement the length of time it will take an average consumer to repay a typical balance in full if he or she makes only the minimum required payment each month. ${ }^{108}$

Credit card issuers engage in intertemporal bundling in response to underestimation of future use by offering low teaser interest rates for an introductory period. Issuers could be required to disclose information on average switching rates or information on the average interest rate that the consumer will pay, accounting for borrowing patterns in both the introductory and post-introductory periods. The evidence suggests that such disclosures would reduce the attractiveness of teaser rate offers. Overestimation of switching affects not only the perceived value of teaser rate offers but also the perceived cost of other mid-stream changes that issuers make. Disclosure of switching rates can help reduce these cost misperceptions as well.

Direct average-use disclosure can also be helpful in other consumer credit markets. Mortgage lenders that offer loans with increasing interest rates could be required to disclose the average balance-weighted interest rate, or the average monthly payment, over the life of the loan. Lenders could also be required to disclose the average likelihood of incurring each of the many penalty fees included in the loan contract and, perhaps, the total fees paid by an average consumer. And in response to consumer optimism

\footnotetext{
106 See S. DellaVigna and U. Malmendier, 'Paying Not to Go to the Gym' (2006) 96 Am. Econ. Rev. 694. Many consumers might think that they will attend the health club more often than the average consumer. Thus health clubs could also be required to provide information on the effective per-visit price paid by an above-average consumer, e.g. a consumer at the eightieth percentile of the distribution. The disclosure could read: 'For $80 \%$ of subscription holders the effective per-visit fee is more than X.'

10712 C.F.R. $\S \S 226.18,226.5$ a.

108 The Bankruptcy Abuse Prevention and Consumer Protection Act of 2005, Public Law 109-8, 119 Stat 23 [hereinafter BAPCPA] $\$ 1301$ (the required disclosure is: 'Minimum Payment Warning: Making only the minimum payment will increase the interest you pay and the time it takes to repay your balance. For example, making only the typical $2 \%$ minimum monthly payment on a balance of $\$ 1,000$ at an interest rate of $17 \%$ would take 88 months to repay the balance in full.'). See also T.A. Durkin, 'Requirements and Prospects for a New Time to Payoff Disclosure for Open End Credit Under Truth in Lending' (2006) FEDS Working Paper No. 2006-34, available at: <http://www.federalreserve.gov/Pubs/feds/2006/200634/200634pap.pdf> (describing the new disclosure requirement). The typical balance stated in Section 1301 is $\$ 1,000$. To what extent this balance is in fact typical is questionable. Moreover, there is a risk that a consumer with a balance of $\$ 5,000$ will simply multiply the disclosed repayment period for a $\$ 1,000$ balance by five, leading to underestimation of the repayment period.
} 
about refinancing options, lenders could disclose the average likelihood of refinancing. Payday lenders could also be required to provide average-use information. Specifically, they could be required to disclose the average number of roll-overs and, based on the average number of roll-overs, the total fee paid by an average consumer. For example, the disclosure could read: 'The fee is $\$ 30$ for a two-week, $\$ 200$ advance. The average borrower renews his or her loan three times (i.e. takes three consecutive advances) before repaying. Therefore, the total fee on a $\$ 200$ loan is $\$ 90$ for an average borrower.'

Average-use disclosures can also prove helpful in the cell-phone market. A common feature of the wireless service contract is the lock-in clause, which ties the consumer to a specific provider for as long as two years. Consumers might underestimate the cost of lock-in. ${ }^{109}$ In fact, in the absence of significant fixed costs, this lock-in feature of wireless service contracts may well be a strategic response to consumers' underestimation of the cost of lock-in. Average-use disclosure can reduce this underestimation bias. Sellers can be required to provide information about the percentage of consumers who stop using their phones, but continue paying for them, before the end of the lock-in period. Sellers can also be required to disclose the percentage of consumers who break the contract and pay the exit penalty.

We have argued that proper-use information is appropriate for use dimensions that have a single, well-defined proper use. When there are many proper uses for a product, proper-use disclosure loses its bite. In such cases, the alternative is averageuse disclosure. But average-use disclosure suffers from a similar limitation. When heterogeneous consumers use the same product in many different ways, average-use information might be of little value. The value of average-use information depends on the degree of heterogeneity. The degree of heterogeneity is a function of both product characteristics and characteristics of the consumer group. But the degree of heterogeneity is also a function of the disclosure regime. The question is whether the seller discloses average-use information where the averaging is done across the entire group of consumers or whether the averaging on which the disclosure is based is done across a smaller, more homogenous subgroup of consumers.

At one extreme, the seller considers the average consumer who enters its store or even the average consumer in the market. Average use, under these assumptions, contains little information. But often the seller has more information - based on demographics, product choice and so forth. Based on this information, the seller can place the consumer in a subgroup of consumers who share a set of observed characteristics. Now average use becomes average use within this subgroup. As the subgroup becomes smaller, the consumer heterogeneity problem decreases and the value of the average-use information increases. Disclosure of average-use information, when averaging is done over smaller subgroups, is advantageous and should be expanded.

\subsection{Individual-Use Information}

The consumer heterogeneity problem limits the efficacy of average-use disclosure. It also supports individual-use disclosure. ${ }^{110}$ In certain markets, where sellers enter into long-term relationships with consumers, sellers can be required to provide the consumer with individualised information on his or her use patterns. An immediate objection to this prescription is that sellers have better information than consumers about the attributes of their product, and that they generally have better information about proper use and average use, but that they do not have better information than the consumer

\footnotetext{
109 Consumers will underestimate the cost of lock-in if they underestimate the likelihood of contingencies that would induce them to end the contract earlier, e.g. the appearance of a more attractive offer from another provider, a change in their need for wireless services or an unanticipated financial hardship that reduces the available income left for non-necessities like wireless phone services. Simple myopia might also lead to underestimation of the cost of lock-in.

110 See also Ayres, above note 103 (arguing for individualised disclosure).
} 
about the individual consumer's use patterns. This is surely true about some products. It is not true about all products. The following examples demonstrate the feasibility of individual-use disclosures in several consumer markets. ${ }^{111}$

\subsubsection{Credit Cards}

The credit card market is an example of an economically significant market where sellers can disclose individual-use information to consumers. Credit card issuers often have more information about how a consumer will use the credit card than the consumer him or herself. First, issuers have detailed statistics about card use, including statistics about card use in the consumer's demographic and socio-economic group. Second, issuers have information on the individual consumer from the credit card application and from credit bureaus. Third, and most importantly, since issuers often maintain long-term relationships with consumers, they quickly obtain information about how the individual consumer uses his or her specific card. Most of this information is available to the consumer, but many consumers do not know or do not remember all the relevant information. Also, many consumers do not consolidate information from these different sources and do not use sophisticated algorithms to analyse the information and predict future use based on this information. Issuers, on the other hand, consolidate all relevant information, store it in databases, update it regularly and analyse it using sophisticated algorithms that can also predict future use. ${ }^{112}$

Recall the late payment and late fee example. We argued that the disclosure of the late fee - a product attribute disclosure - might be less effective if many consumers underestimate the likelihood of paying late. In discussing average-use disclosures, we suggested mandating disclosure of the number of late payments that an average consumer makes over a one-year period. We also noted the limits of such a disclosure, as most consumers will optimistically believe that they will pay late less often than the average consumer. A better solution is to require disclosure of individualised late payment information. ${ }^{113}$ Issuers keep records on consumers' late payments. They can be required to disclose the number of late payments made by the specific consumer or the total amount of late fees paid by the consumer over the past year. ${ }^{114}$

\footnotetext{
111 Scepticism about the feasibility of regulations requiring disclose of actual individualised information was recently expressed by Christine Jolls and Cass Sunstein. See C. Jolls and C.R. Sunstein, 'Debiasing through Law' (2006) 35 J. Legal Stud. 199, 209 (rejecting the possibility of requiring the disclosure of individualised information about product risk). Jolls and Sunstein write that 'it is difficult to imagine incorporating such individualised information into a general legal standard'. The disclosure regulation proposed below is not in the form of a general legal standard. Rather, we advocate market-specific disclosure mandates. In addition to the feasibility concern, individualised disclosure raises a privacy concern. At this point, however, we propose disclosure only of information that sellers collect anyway. However, if disclosure requirements affect sellers' information collection and retention practices, then the privacy concern will have to be addressed.

112 See M. Furletti, 'Credit Card Pricing Developments and Their Disclosure 6-9' (2003) Federal Reserve Bank of Philadelphia, Payment Cards Center, Discussion Paper, available at: <http://www.philadelphiafed. org/pcc/papers/2003/CreditCardPricing_012003.pdf $>$ Duncan McDonald, former general counsel of Citigroup's Europe and North America card businesses, notes: 'No other industry in the world knows consumers and their transaction behavior better than the bank card industry. It has turned the analysis of consumers into a science rivaling the studies of DNA ... The mathematics of virtually everything consumers do is stored, updated, categorized, churned, scored, tested, valued, and compared from every possible angle in hundreds of the most powerful computers and by among the most creative minds anywhere. In the past 10 years alone, the transactions of 200 million Americans have been reviewed in trillions of different ways to minimize bank card risks.' See D.A. MacDonald, 'Viewpoint: Card Industry Questions Congress Needs to Ask' (2007) American Banker 10.

113 There may still be optimism at play, limiting the effectiveness of even individualised disclosure. A consumer might be forced to acknowledge that he or she, not some average consumer, has paid a lot of money in late fees over the past year, but may still believe that he or she will not repeat this behaviour in the future. Of course, such optimism will become less likely as the disclosed history reveals year after year of high penalty payments.

114 Issuers provide year-end summaries with individualised information. These summaries, however,
} 
We now move from late fees to over-limit fees. Disclosure of individualised usepattern information can also be effective when provided at the point of sale. Professor Ronald Mann proposed that issuers be required to disclose, through merchants, when a certain purchase would take the consumer over his or her credit limit, triggering an over-limit fee. Such a disclosure could help the consumer to avoid inadvertently exceeding his or her credit limit, perhaps by switching to another card or to another payment system. ${ }^{115}$ With respect to the debt-repayment dimension, we noted the recent addition of an average-use disclosure mandate requiring issuers to provide, on the monthly statement, information on the average length of time it will take to pay off a typical balance if the consumer makes only the minimum payment each month. ${ }^{116}$ The new disclosure has an individual-use component as well. Issuers must provide a phone number that the consumer can call to receive information on the length of time it will take that consumer to pay off his or her specific balance if the consumer makes only the minimum payment each month. While this option to receive individualised repayment rate information is a step in the right direction, it would probably be more effective if the individualised disclosure was provided automatically on each monthly statement. ${ }^{117}$

\subsubsection{Cell Phones}

The cellular phone market is an example of another economically significant market where the long-term relationship between providers and consumers allows for the provision of individualised use-pattern information. Evidence of consumer mistakes in the cell phone market suggests that such individualised disclosure may be helpful. A notable design feature of mobile service contracts is the steep jump in per minute charges when the consumer exceeds the plan limit. Many contracts specify an increase of over $100 \%$ in the per-minute price, with some contracts specifying increases of $200 \%$ and beyond. ${ }^{118}$ Arguably, the high prices set for minutes beyond the plan limit target consumers' underestimation of their future use of the cellular phone. ${ }^{119}$

Individualised disclosure can reduce consumer mistakes about cell phone use. In particular, sellers can provide individualised use information, focusing the consumer's attention on use exceeding the plan limit. ${ }^{120}$ This disclosure could be supplemented by information on alternative service plans that would reduce the total price paid by the consumer, given his or her current use patterns. ${ }^{121}$ Individual-use information can be especially helpful for consumers who inadvertently exceed the plan limit. The challenge of keeping track of cumulative use has increased with the invention of multiple-

focus more on spending behaviour and less on borrowing behaviour (see e.g. the 'Year-End Summary' feature offered by several credit card companies, which provides an annual itemised list of all charges). Accordingly, the total amount paid in interest charges or late fees is not disclosed.

115 See Mann, above note 3, at 162. A proposed bill, H.R. 1052, 107th Cong. (2001), in Section 10, goes beyond disclosure and prohibits the imposition of over-limit fees for creditor-approved transactions.

116 BAPCPA, § 1301. See also Durkin, above note 108 (describing the new disclosure requirement)

117 Compare $\S 2$ of the proposed bill, H.R. 1052, 107th Cong. (2001). See also Mann, above note 3, at 160161 (proposing an individualised disclosure on the monthly bill and arguing that such a disclosure is not too costly to implement).

118 See S. DellaVigna and U. Malmendier, 'Contract Design and Self-Control: Theory and Evidence' (2004) 119 Quarterly Journal of Economics 353 at 380; Verizon Wireless, America's Choice ${ }^{\circledR}$ Basic Plans, available at: <http://www.verizonwireless.com> (last visited 5 June 2007) (quoting mark-ups in excess of $300 \%$ for minutes beyond the plan limit). See also Nalebuff and Ayres, above note 103, at 178-179 (describing the high post-plan minute prices as 'hidden pricing').

119 Clearly, these huge increases do not reflect a corresponding change in the provider's per-minute cost. See M.D. Grubb, 'Selling to Overconfident Consumers' (2007) (unpublished manuscript), available at: $<$ http://ssrn.com/abstract=721701>; O. Bar-Gill and R. Stone, 'Mobile Misperceptions' (2009) 23 Harvard Journal of Law \& Technology.

${ }_{120}$ Or to use that is substantially below the plan limit and would merit a switch to a lower limit/lower fee plan. Carriers, both in the United States and in Europe, already provide certain use information on the monthly bill.

121 Utility companies in Germany have voluntarily adopted an even more pro-consumer policy. At the end of the year, they retroactively match each consumer to the service plan under which the consumer pays the lowest total price given his or her use over the past year. See Nalebuff and Ayres, above note 103, at 27. 
limit plans, e.g. plans with different limits for peak and off-peak minutes. To reduce the incidence of inadvertently exceeding the plan limit, issuers could be required to notify consumers, via a recorded message or a text message, when they are about to exceed the plan limit. A consumer receiving such notification may well decide to cut the conversation short, switch to a land line or postpone the conversation until off-peak hours. ${ }^{122}$

\subsubsection{Other Markets}

Sellers have individual-use information in many other markets. Some of this information is currently being disclosed to consumers, but enhanced disclosure requirements may be desirable. For example, phone (not cell phone) companies disclose certain use information to consumers on their monthly bills. More effective disclosure would include use patterns averaged across several months, perhaps accompanied by total cost information under the consumer's current plan as well as under alternative plans offered by the phone company. ${ }^{123}$ Health clubs could also be required to disclose individualised use-pattern information. Specifically, health clubs could disclose attendance records for the past year and even for the preceding year (or years). They could also calculate and disclose the per-visit fee paid by the individual subscription-holder. Faced with such information when asked to renew the subscription, the consumer may well decide to forgo the subscription and pay on a per-visit basis. Similarly, a retailer asking a consumer to renew a membership card or a discount card could be required to disclose the total savings enjoyed by the individual consumer over the past year. This information would assist the consumer in making a more informed decision as to whether to pay the annual fee and renew the membership.

Netflix effectively competes with traditional video rental stores through a unique business model. For a constant monthly fee, the consumer gets a specified number of movies, say three movies. The consumer can keep these three movies for as long as he or she likes. Whenever a movie is sent back to Netflix, the company promptly replaces it with the next movie on the consumer's priority list. Under this model, a consumer who sees two movies a month pays the same price as a consumer who sees twenty movies a month. The question is whether consumers correctly anticipate their in-home movie-viewing patterns. Netflix could easily prevent consumers from making use-pattern mistakes. It could disclose the average number of videos that an individual consumer receives in a month, as well as the average price that the consumer pays per movie. With this information, the consumer would be able to compare prices across the different business models and make a more educated choice between Netflix and, say, Blockbuster. ${ }^{124}$

Finally, simple disclosure could assist consumers who forget to cancel a service at the end of the introductory period. Service providers know precisely when the introductory period ends for each individual consumer. The service provider could be required to send a notice to each consumer two weeks before the introductory period ends for the individual consumer. This notice would remind the consumer that the low introductory

\footnotetext{
${ }_{122}$ Compare 'usage alert' mandates in Art. 6(a)(2) of Regulation (EC) No. 544/2009 of the European Parliament and of the Council of 18 June 2009, amending Regulation (EC) No. 717/2007 on roaming on public mobile telephone networks within the Community and Directive 2002/21/EC on a common regulatory framework for electronic communications networks and services. In the United States, the FCC is considering similar regulations. See Federal Communication Commission, Public Notice: Comment Sought on Measures Designed to Assist U.S. Wireless Consumers to Avoid 'Bill Shock', CG Docket No. 09-158, 11 May 2010.

${ }_{123}$ Utility companies also provide some individualised use-pattern information on the monthly statement. For instance ConEdison provides information on the individual consumer's average daily use of electricity for previous months.

124 To further facilitate a comparison between Netflix and video rental stores that follow a traditional business model with late fees, Netflix's competitors could be required to disclose the number of late payments made by the specific consumer or the total amount of late fees paid by the consumer over the past year. Of course, such individual-use disclosure is only feasible for consumers who maintain a long-term relationship with the video rental store (e.g. consumers who hold a membership card).
} 
price will soon be replaced by a higher post-introductory price and describe a lowcost way to discontinue the service. This disclosure would prevent many inadvertent continuances of service beyond the introductory period. ${ }^{125}$

\subsection{Designing Optimal Use-Pattern Disclosure}

One of the main goals of this article is to establish use-pattern disclosure as a complement to product attribute disclosure in addressing behavioural market failures. Product-use information is clearly important for consumer decision-making and for the efficient operation of consumer markets. But this is not enough. Successful disclosure regulation must effectively convey use-pattern information to consumers. The question is how to optimally design disclosure regulation. We do not purport to provide a comprehensive answer in this article. ${ }^{126}$ Still, the preceding discussion offers some general guidelines. First, when possible, use-pattern disclosure should be based on individual-use information. And when use-pattern disclosure is based on average-use information, the averages should be taken over a cost-effectively small subgroup of consumers.

Second, in many cases, disclosure mandates should combine product attribute and product use information. For example, a consumer will benefit from a disclosure stating the number of late payments he made on a credit card over the past year. He or she will likely benefit even more from a disclosure that by combining price information and use information states the total amount that the consumer paid in late fees over the last year. And the most informative disclosure would combine price and use information in multiple dimensions. Such disclosure would state the total amount that the consumer paid in penalty fees and interest, including late fees, over-limit fees, penalty interest payments and so forth. The goal is to come as close as possible to Total Cost of Ownership (TCO) information. Due to the existence of multiple price dimensions and the fact that the relative importance of different price dimensions depends on use patterns, calculating total price can be difficult. Sellers should be required to make these calculations for consumers. Disclosure regulation should strive to provide consumers with meaningful price information in a simple, accessible way. ${ }^{127}$

\subsection{The Costs and Limits of Disclosure}

This article focuses on disclosure regulation because, compared to other forms of regulation, it is more compatible with free markets and, in most cases, more politically

\footnotetext{
125 There is evidence that such inadvertent continuances are common. A recent bill introduced in the Israeli parliament (the Knesset) proposes a regulatory response similar to the one described in the text. Opposition to this bill by service providers suggests that inadvertent continuances are common and constitute a substantial revenue source for these service providers. See R. Linder-Ganz and Z. Zarhiya, 'Bill Prohibiting Automatic Contract Renewal Stuck in Committee', Haaretz (2007). In the United States, state legislators have also been concerned about the problem of automatic contract renewal following a low-price introductory period. See e.g. Illinois Automatic Contract Renewal Act, 815 I.L.C.S. 601/1 et seq (sellers must provide consumers with written notice of the automatic renewal no less than 30 days or more than 60 days prior to the date of the cancellation deadline for the renewal). Other state laws require only that sellers provide a general notice about cancellation rights, not an individualised notice prior to the end of the introductory period for the specific consumer. See e.g. Act Concerning Enforceability of Automatic Contract Renewal Provisions, H.R. 7204, Gen. Assem., Jan Sess. (Conn. 2007). See also HB 1702, 80th Leg. (Tex. 2007); S. 527, 2007 Gen. Assem., Reg. Sess. (N.C. 2007).

126 On the optimal design of disclosure regulation, see e.g. Jolls and Sunstein, above note 111; Beales, Craswell and Salop, above note 18, at 529-531; Craswell, above note 39; L. Froeb et al., 'Economic Research at the FTC: Information, Retrospectives, and Retailing' (forthcoming) Review of Industrial Organisation, available at: <http://papers.ssrn.com/sol3/papers.cfm?abstract_id=592101> (last visited 13 March 2010); J.M. Lacko and J.K. Pappalardo, 'The Effect of Mortgage Broker Compensation Disclosures on Consumers and Competition: A Controlled Experiment' (2004), available at: <http://www.ftc.gov/os/2 004/01/030123mortgagesummary.pdf $>$ (the FTC is studying the efficacy of different disclosure techniques in the home mortgage market).

127 See Craswell, above note 39, at 692-694 (discussing single-price disclosures and detailing the costs of such disclosures).
} 
feasible. This does not mean that disclosure is always effective. Nor does it mean that disclosure, when effective, is without cost. We now consider the main costs of disclosure mandates and the main limits on the efficacy of disclosure regulation. We begin with the general costs and limits of disclosure regulation. We then describe additional costs and limits specific to average-use disclosure. The shortcomings of average-use disclosure indirectly support an expansion of individual-use disclosure. ${ }^{128}$

\subsubsection{The Costs of Disclosure}

We begin with the direct costs of disclosure. These include the cost to sellers of collecting, compiling and distributing the information. They also include the cost to consumers who need to read the disclosure and process the disclosed information. In many of the examples provided in this article, the direct cost to sellers only amounts to the relatively minor cost of distributing the information. The reason for this is that sellers collect and compile the relevant information anyway. Credit card issuers, for example, have a powerful business motivation to obtain information on consumers' use patterns.

This relates to another, indirect cost of disclosure regulation. If sellers are required to disclose the information they collect, then they will have a weaker incentive to collect information. ${ }^{129}$ While this adverse incentive effect is undeniably true, its magnitude can be expected to be small in many markets, as the business reasons for collecting information will often outweigh the disclosure disincentive. ${ }^{130}$ Moreover, disclosure mandates commonly imply an obligation to collect the information to be disclosed. Of course, when the information would not have been collected absent the mandate, the cost of collection constitutes a cost of the disclosure regulation - a cost that will be passed on, at least in part, to consumers. And, in some markets, this cost might be so large that it would drive sellers out of the market.

\subsubsection{The Limited Efficacy of Disclosure}

One of the main limits on the efficacy of disclosure regulation concerns information overload. There is a limit on the amount of information that the average consumer can effectively process. Accordingly, disclosed information might be ignored or might replace other information, perhaps more important information, in the consumer's decision-making process. The information overload problem cautions against increasing the amount of information disclosed. ${ }^{131}$ Even if consumers can process the disclosed information, it is not clear that they will do so. Provision of information, specifically usepattern information, can be helpful if consumers follow a deliberative decision-making process (even if this decision-making process is not fully rational). However, there is

\footnotetext{
128 The costs and limits described below reduce the appeal of disclosure regulation even when designed and administered by regulators seeking to advance the public good. Unfortunately, not all regulators share this goal, and regulatory decision-making is too often guided by politics, not by the public good. Of course, these concerns apply to all forms of regulation and not specifically to disclosure regulation or to use-pattern disclosure.

129 Compare A.T. Kronman, 'Mistake, Disclosure, Information, and the Law of Contracts' (1978) 7 J. Legal Stud. 1 (arguing that contract law disclosure obligations might deter the acquisition of information). ${ }_{130}$ Kronman distinguishes between deliberately acquired information and casually acquired information and argues that casually acquired information can be subject to disclosure mandates. Id. In Kronman's terms, much of the information that sellers should disclose is casually acquired, i.e. it would have been acquired by sellers anyway for business reasons.

${ }_{131}$ See e.g. Craswell, above note 39 (arguing that provision of additional information dilutes the effectiveness of existing disclosures); Korobkin, above note 11 (consumers can process only limited amounts of information); Government Accountability Office, 'Credit Cards: Increased Complexity in Rates and Fees Heightens Need for More Effective Disclosures to Consumers' (2006) at 46, available at: <http:// www.gao.gov/new.items/d06929.pdf> (finding that credit card disclosures contain too much information); Furletti, above note 112, at 19 (concluding that it is not clear that requiring more details in regulatory disclosures would be useful for consumers.); Latin, above note 11.
} 
evidence that, in some cases, consumer decision-making is driven by an emotional response rather than by a deliberative process or that emotions influence the deliberative process. ${ }^{132}$ In these cases, disclosure regulation will be less effective.

Finally, even if consumers can process use-pattern information and would like to do so, the required information might not exist. This problem is especially acute with respect to new products. It takes time to collect information about average use. And the absence of historic information precludes individual-use disclosure. Moreover, these practical impediments to effective disclosure regulation can be manipulated by sellers. For example, in order to evade disclosure mandates, sellers might try to present a slightly modified version of a product as a new product.

\subsubsection{The Limited Efficacy of Average-Use Disclosure}

Average-use disclosure is subject to additional limitations. These limitations reinforce the case for individual-use disclosure. The first, inherent limitation is an immediate implication of consumer heterogeneity. Averaging, by its very nature, implies loss of information. As the degree of heterogeneity among the relevant group of consumers increases, the value of average information decreases. For this reason, if sellers segment the market into small subgroups of consumers and can be required to disclose averageuse information within these more homogeneous subgroups, the value of the disclosure increases. ${ }^{133}$

Optimism imposes another limit on the efficacy of average-use disclosure. Most consumers will optimistically think that they are above average - that they will be late less often than the average consumer in paying their credit card bill, that they will repay their bill more quickly than the average consumer, that they are less likely than the average consumer to break their lock-in cell-phone contract and so forth. Still, averageuse information can be helpful. Consumers suffer from two types of misperception: (1) misperception about the mean; and (2) misperception about their position relative to the mean. ${ }^{134}$ Average-use information can be helpful in curing the former misperception.

Moreover, optimally designed average-use information can minimise the optimism problem. First, measuring and disclosing average-use across smaller, more homogeneous groups of consumers should reduce the 'we are all above average' problem. Second, more sophisticated use of statistical information can reduce the optimism problem. Statistical use information need not be limited to straight averages. To take a specific example, the fact that an average consumer pays \$200 in penalty fees over the course of the year might be dismissed by most consumers as irrelevant to them. These consumers will find it more difficult to dismiss the fact that $80 \%$ of consumers pay more than $\$ 100$ a year in penalty fees. Disclosure of statistical use information describing the behaviour of a supermajority of consumers should reduce the optimism problem. ${ }^{135}$

Finally, average-use disclosure might suffer from an endogeneity problem. Consider the rebates example. Assume that, absent disclosure, only 5\% of consumers redeem the rebate. If the seller discloses this 5\% figure, then most consumers will respond by ignoring the rebate and focusing on the pre-rebate price. These consumers will purchase a product with no rebate and a lower spot price. Still, a minority of highly motivated rebate users will prefer rebate pricing. And, in time, the rate of redemption, among this minority of rebate users, will rise to, say, $90 \%$. If the seller updates the disclosure from a $5 \%$ redemption rate to a $90 \%$ redemption rate, there is a risk that the majority

\footnotetext{
132 See e.g. J. O'Shaughnessy and N.J. O'Shaughnessy, The Marketing Power of Emotion (2002).

133 See Craswell, above note 39, at 691-692 (discussing heterogeneity as a limit of disclosures based on averages; Craswell does not focus on average use).

134 See Latin, above note 11, at 1243-1244.

135 Of course, individual-use disclosure, when feasible, is the best way to minimise the optimism effect. But even individualised disclosure is not a perfect cure for optimism. Individualised disclosure is based on historic information. An optimistic consumer might convince him or herself that she will not repeat the mistakes of the past. For example, a consumer who is confronted with information about the amount of late fees that he or she paid over the past year might refrain from switching to a credit card with lower late fees because he or she optimistically believes that he or she will not be late next year.
} 
of consumers will again opt for rebate pricing. The redemption rate will then drop back to $5 \%$, the disclosure will be updated again and so forth. This dynamic is undesirable. But the endogeneity problem will often be mitigated by market forces. In the rebates example, if a seller expects that after disclosing the 5\% redemption rate only highly motivated rebate users will prefer rebate pricing, it will have to reduce the magnitude of the rebate significantly to avoid a loss. Accordingly, the seller will be able to advertise a $90 \%$ redemption rate only for minor rebates. ${ }^{136}$

\subsubsection{Voluntarily-Supplied Use-Pattern Information}

A cost-benefit analysis of any use-pattern disclosure mandate should consider the usepattern information that is being voluntarily provided in the marketplace. The benefit of a disclosure mandate will generally be smaller when use-pattern information is already available. ${ }^{137}$ And this smaller benefit may no longer justify the cost of the disclosure regulation. Use-pattern information is voluntarily provided by sellers and by third parties in some cases. For example, sellers routinely provide proper-use information, even absent a legal mandate. Tobacco companies voluntarily disclose tar and nicotine levels. Utility companies, cell phone service providers, credit card issuers and other sellers provide some use information on the monthly bill. Amazon and Netflix compile use-pattern information and use it to inform consumers about books and movies enjoyed by other consumers with similar use patterns. And more.

Use-pattern information is also provided by third parties, like Consumer Reports and CNet.com. For example, Consumer Reports provides proper-use information about child car seats, lawnmowers and many other products. ${ }^{138}$ And CNet.com provides use information and Total Cost of Ownership information on home printing, for example. ${ }^{139}$ When information is provided by the market - by sellers or by third parties - the need for disclosure regulation is diminished. The problem, of course, is that the market will not always provide sufficient information. When buyers understand the extent and cost of their ignorance, they will become informed or generate demand for information that would motivate both sellers and third parties to provide this information. But buyers are not always aware of their ignorance (or of the cost of their ignorance). And, absent such rational demand for information, the imperfect alignment between seller interests, and even third-party interests, and consumer interests might lead to failure in the market for information. ${ }^{140}$ When such a market failure exists, disclosure regulation may be socially desirable.

\footnotetext{
136 Health club subscriptions provide another example. Assume that the average consumer who purchases a health club subscription attends the club ten times a year. If this information is disclosed, and if this disclosure is effective, many consumers who previously purchased a subscription will now choose the pervisit pricing option, and only heavy users will purchase a subscription. Accordingly, the average attendance of a subscription holder would rise to, say, fifty visits a year. The health club would have to update its disclosure. And there is a risk that with the new disclosure consumers will again opt for a subscription. Of course, if they do, then the disclosure will need to be updated again: back to an average attendance of ten times a year. Again market forces mitigate the problem. If, following the initial disclosure, only heavy users purchase subscriptions, then the subscription price will increase significantly. And this increased price will minimise the number of light users who opt for a subscription, even when the disclosure is updated to the new fifty visits per year average.

137 We assume that anti-fraud law effectively polices the accuracy of the voluntarily disclosed use-pattern information.

138 See ConsumerReports.org, 'Buying Advice: Child Car and Booster Seats', available at: $<$ http://www. consumerreports.org/cro/babies-kids/child-car-booster-seats/reports/how-to-choose/index.htm> (last visited 8 August 2007) (child car seats); ConsumerReports.org, 'Equipment Care', available at: <http:// www.consumerreports.org/cro/home-garden/news/october-2006/end-of-season-lawn-and-equipmentguide-10-06/equipment-care/0610_end-of-season-lawn-and-equipment-guide_equipment-care.htm> (last visited 8 August 2007) (lawnmowers).

139 See CNet.com, 'Printer Buying Guide', available at: <http://reviews.cnet.com/4520-7604_7-1016838-

5.html?tag=tnav $>$ (last visited 8 August 2007).

${ }_{140}$ See also above Section 2.2.2.
} 


\subsubsection{The Costs and Limits of Disclosure - Summary}

Disclosure regulation is only partially effective, and its limited benefits are often offset by countervailing costs. This article is not a call for expanded disclosure. Rather, it argues that, within the vast landscape of disclosure regulation, too little attention has been paid to use-pattern disclosure. ${ }^{141}$ Accordingly, the implications of our analysis are not necessarily more disclosure. In many markets, applying the analysis developed in this article will require substituting some product attribute disclosure with use-pattern disclosure or modifying existing use-pattern disclosures. To the extent that disclosure regulation is socially desirable, the goal is to design the best possible disclosure regime. This regime will feature an optimal mix of product attribute disclosures and use-pattern disclosures.

Most importantly, the cost-benefit analysis that should guide regulators in designing an optimal disclosure regime must be a market-specific analysis. Only an in-depth inquiry into the specific market can identify a behavioural market failure - a persistent consumer mistake that causes substantial welfare loss. And only an in-depth marketspecific analysis can determine the optimal regulatory response to the identified market failure. This article establishes the framework for identifying use-pattern mistakes and for designing a disclosure-based regulatory response to use-pattern mistakes. Applying this framework to specific consumer markets must be left for future research. ${ }^{142}$

\section{Conclusion}

Before purchasing a product, the consumer forms a mental image of how he or she will use the product. This image is not always accurate. Mistakes in estimating product use affect the perceived benefits and costs associated with a product and can lead to welfare-reducing transactions. The law plays an important role in facilitating the efficient operation of markets by requiring disclosure of information that minimises consumer mistakes. And when the problem is use-pattern mistakes, the cure must be use-pattern disclosure. Existing use-pattern disclosures are largely confined to properuse information and to average-use information, indirectly disclosed as a benchmark for product attribute disclosures. Policy-makers should consider increasing the number and quality of use-pattern disclosure requirements. In particular, disclosure of individual-use information should be considered in markets characterised by long-term relationships between sellers and consumers.

While this article focuses on disclosure regulation as a policy response to use-pattern mistakes, other, structural responses should be considered when applying the proposed framework to specific consumer markets. In particular, legal intervention establishing a time-limited consumer right to return a product or discontinue a service provides another regulatory response tailored to the unique characteristics of use-pattern mistakes. Ideally, after using the product or service for a period of time, the consumer will learn the necessary use-pattern information and will be better equipped to choose among competing products. ${ }^{143}$

\footnotetext{
141 As the preceding discussion makes clear, the costs and limits of disclosure affect both product attribute disclosures and use-pattern disclosures.

${ }_{142}$ In theory, the call for a market-specific analysis invokes the problem of defining the relevant market. While the market-definition problem is a major problem in antitrust law, it should not pose a significant hurdle in the present consumer protection context. At the very least, there is a sufficiently large number of consumer markets where the proposed framework can be fruitfully applied without bumping against boundary questions of market definition. And, in many contexts, regulators should be able to base their policy analysis on a largely uncontroversial market definition that is functionally based on the identified objectionable design feature.

${ }_{143}$ Of course, the details of such a policy will have to be worked out on a market-by-market basis Moreover, the policy will be inapplicable in many markets. Still, the structural connection of this policy to use-pattern mistakes and the potentially small burden it imposes on the operation of markets justify its consideration by policy-makers. Compare Camerer et al., above note 2 (noting cool-off periods as an example of asymmetrically paternalistic regulation).
} 